\title{
Multidrug Resistance Transporters - Roles in maintaining Cancer Stem-Like Cells
}

\author{
To, Kenneth K.W. ${ }^{1}$ and Fu, L.W. ${ }^{2}$ \\ 1School of Pharmacy, The Chinese University of Hong Kong, Hong Kong \\ 2 State Key Laboratory of Oncology in South China, Cancer Center, Sun Yat-Sen \\ University, Guangzhou \\ China
}

\section{Introduction}

Cancer has become the leading cause of death worldwide in the year 2010, according to a new edition of the World Cancer Report from the International Agency for Research on Cancer (World Health Organization, 2010). Despite the advance in the development of novel chemotherapeutic drugs, the dismal prognosis facing most cancer patients may result from the ability of cancer to withstand drug treatment, recur and metastasize after initial therapies. There is accumulating evidence in support of a central role for cancer stem cells (CSCs) in the initiation, propagation and recurrence of human cancers. Therefore, targeting CSCs has become an attractive research topic for the improvement of treatment outcome and prolongation of patient survival. However, CSCs are endowed with the ability to survive against chemo- and radiation therapy. A better understanding of the mechanisms underlying CSC resistance is badly needed. This chapter provides a review about evidence supporting a fundamental role for CSCs in cancer progression, and summarizes potential mechanisms of CSC resistance to treatment, with emphasis on the involvement of multidrug resistance transporters and their regulation in CSCs.

\section{The Cancer Stem Cell (CSC) hypothesis}

For many years, tumors have been described as the proliferation of cell clones in which multiple genetic alterations had occurred over time (Nowell, 1976). This "clonal evolution" model is a non-hierarchical model that proposes all cells within a tumor would have an equal chance of acquiring genetic mutations necessary for driving the tumor growth. Subsequently, under selective pressures, the more aggressive cells would drive the tumor progression and lead to therapy resistance. Distinct from this notion, an emerging "cancer stem cell model" is a hierarchical model, which proposes that only a subset of cells called "cancer stem cells" (CSCs) or "tumor-initiating cells" can initiate and propagate a tumor. The CSCs can self-renew, propagate the tumor, and differentiate into the diverse types of cells that are found in the original tumor, thereby mimicking stem cells.

The emergence of the CSC model can be dated back to the mid-19th century when a German pathologist Rudolf Virchow proposed that cancers arise from the activation of dormant, embryonic-like cells present in mature tissue (Virchow, 1855). His speculation was based on 
the histological similarities between the developing fetus and certain types of cancer such as teratocarcinomas. Later, the term "cancer stem cells" was probably first coined by Hamburger and Salmon who postulated that a subpopulation of cells in a tumor capable of growing in soft agar are the cell renewal source of a neoplasm and also serve as the seeds of metastatic spread of cancer (Hamburger \& Salmon, 1977). More recently, the first conclusive evidence for CSCs was reported in 1994 when John Dick and colleagues isolated the cancerous stem cells from acute myelogenous leukemia and documented their self-renewing capacity (Lapidot et al., 1994).

Since then, the CSC hypothesis has shifted the paradigm in our understanding of cancer tumorigenesis and has important implications in cancer chemotherapy. With respect to tumor development and progression, it could explain the well-known heterogeneous nature of cells in a tumor (Park et al., 1971). While CSCs represent the only cells with self-renewal capability driving the tumor growth, the remaining actively proliferating cells making up the bulk of the tumor could still differentiate and are therefore destined to die. Therefore, the goal of cancer chemotherapy should be to target these CSCs for complete eradication of the tumor.

It should be noted that the CSC hypothesis indeed does not specify the origin of the cancer initiating cells. They could originate from a stem, progenitor or differentiated cell. Therefore, the term "tumor-initiating cell" is often used instead of cancer stem cells to avoid the confusion. The prevailing thought is that CSCs are derived through an activation process involving one of three possible pathways (Figure 1): (1) from normal stem cells losing growth regulation; (2) from progenitor (Jamieson et al., 2004; Krivtsov et al., 2006) or differentiated cells acquiring the self-renewal capacity; or (3) by the fusion of normal stem cells with cancer cells (Pawelek \& Chakraborty, 2008; Dittmar et al., 2009).

\subsection{Detection and identification of CSCs}

The general consensus nowadays is that CSCs can only be ultimately defined experimentally by their ability to recapitulate the generation of a continuously growing tumor (Clarke et al., 2006). However, due to technical difficulty of tumor repopulation in vivo, three other popular molecular or phenotypic characteristics of CSCs are being exploited for their identification and prospective isolation from tumor specimens and cancer cell lines. These include (1) the "side population (SP)" phenotype manifested by the exclusion of Hoechst 33342 dye in flow cytometric assays; (2) cell surface markers; and (3) anchorage-independent sphere formation ability. The putative CSC population thus identified will usually be further validated by their ability to initiate a tumor and subsequently recapitulate the heterogeneity of the primary tumor.

\subsubsection{The "side population (SP)" phenotype}

CSCs and the normal stem cells alike express high levels of the ATP-binding cassette (ABC) transporters, which help protect them from cytotoxic insult throughout their long lifespan. By using the energy of ATP hydrolysis, ABC transporters actively efflux drugs out of the cells, thereby protecting them from toxic xenobiotics (Gottesman et al., 2002). Importantly, this drug-efflux capability conferred by ABC transporters (including ABCG2 and P$\mathrm{gP} / \mathrm{MDR} 1$ ) has been used as a marker in the isolation and analysis of haematopoietic stem cells (HSCs). Goodell and colleagues were the first to report that when mouse bone marrow-derived cells are incubated with the dye Hoechst 33342 and then analyzed by dual- 
wavelength flow cytometry, a small population of cells does not accumulate an appreciable amount of the fluorescent dye and is thus identified as a Hoechst-dim side population (SP) (Goodell et al., 1997). Remarkably, the side population is highly enriched in HSCs (Goodell et al., 1996). When isolated from mice and transplanted into irradiated mice, small numbers of these SP cells can reconstitute the bone marrow, demonstrating that these cells are pluripotent. Later, it was demonstrated that the transporter Abcg2, but not P-gp/Mdr1, was responsible for the SP in mouse bone marrow (Zhou et al., 2001). Human ABCG2 was subsequently also found to be responsible for the SP phenotype in human bone marrow (Scharenberg et al., 2002).

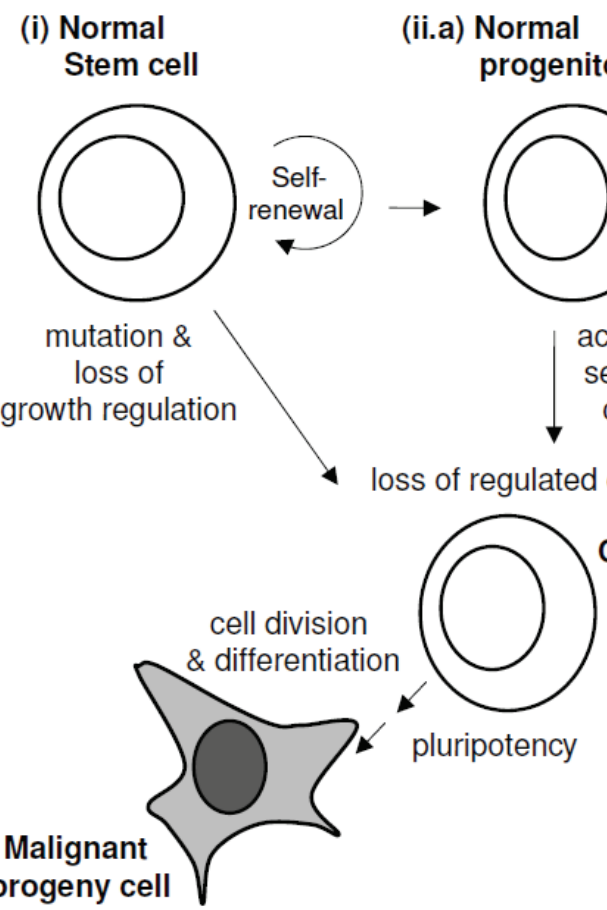

\section{(ii.b) Committed / differentiated cell}
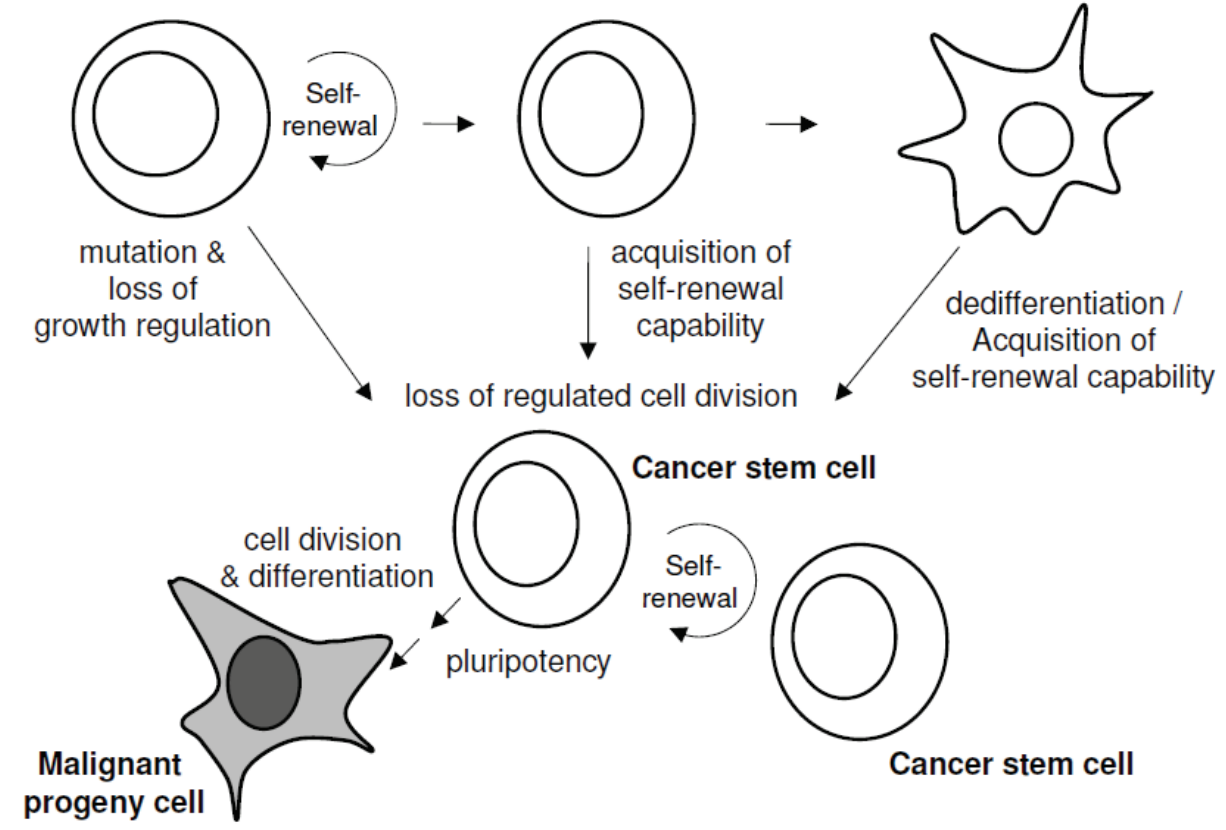

Fig. 1. Origin of CSCs (tumor-initiating cells). A CSC may arise from one of the following molecular pathways: (i) a stem cell undergoing a mutation; (iia \& iib) a progenitor/differentiated cell undergoing several mutations, thus allowing them to acquire the self-renewal ability; (iii) fusion of a cancer cell with a normal stem cell, thereby equipping the former with self-renewal capability (not shown in the figure). Like normal stem cells, CSCs are capable of long-term self-renewal and dividing asymmetrically to recapitulate the generation of a continuously growing tumor (pluripotency). In all scenarios, the resulting CSC has lost normal growth regulation and progress into malignancy.

Since its initial application in bone marrow HSCs, the side population technique based on Hoechst 33342 efflux has been adapted to identify putative stem cells and progenitors in many normal tissues (Zhou et al., 2001; Asakura \& Rudnucki, 2002; Leckner et al., 2002; Alvi et al., 
2003; Summer et al., 2003; Budak et al., 2005; Du et al., 2005, Hussain, et al., 2005). SP cells have also been found in a number of established cancer cell lines as well as tumor samples and have been shown to have stem cell-like properties, overexpress ABCG2, and possess inherent drugresistance (Kondo et al., 2004; Hirschmann-Jax et al., 2004; Haraguchi et al., 2005; Seigel et al., 2005, Chiba et al., 2006). Figure 2 shows the existence of such a SP in a ABCG2-overexpressing mitoxantrone-selected resistant pancreatic cell line. The nearly complete elimination of all SP cells after treatment with the specific ABCG2 inhibitor, fumitremorgin C (FTC), suggests that $\mathrm{ABCG} 2$ is a major molecular determinant for the SP phenotype.

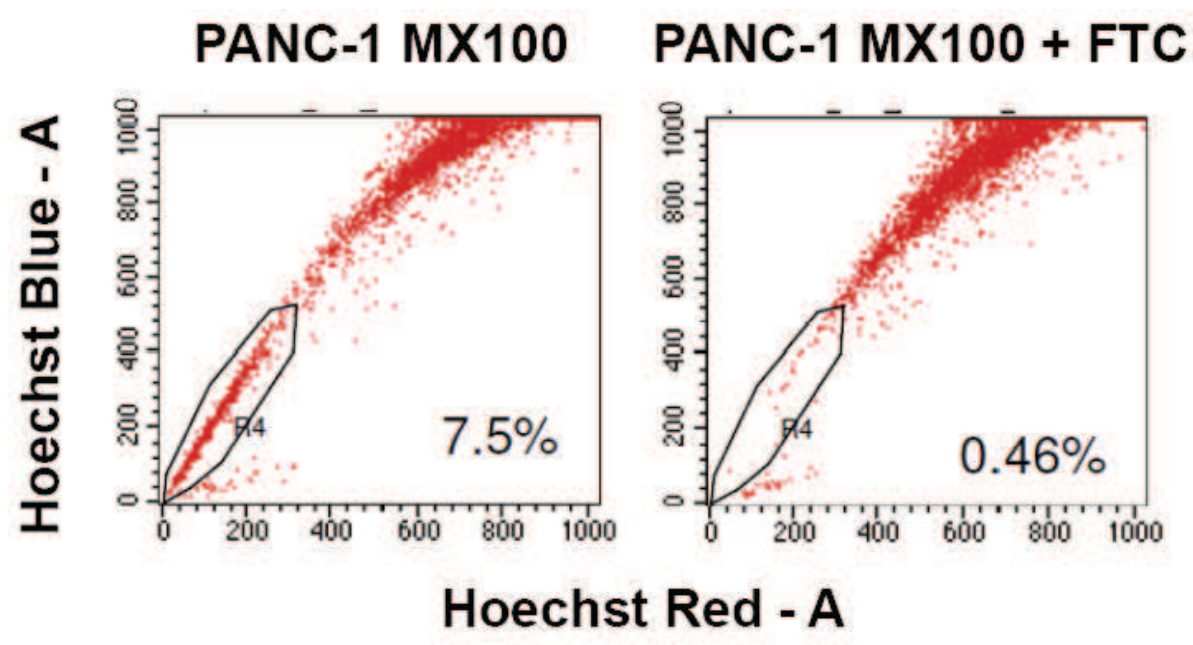

Fig. 2. Identification and isolation of SP cells for the study of putative CSCs. FACS analysis was performed for a mitoxantrone-selected drug-resistant and ABCG2-overexpressing pancreatic cancer cell line after incubation with Hoechst 33342 dye for $1 \mathrm{~h}$. The gated R4 region represents a Hoechst staining-resistant cell population (i.e. SP cells); their abundance are indicated by the number in the figure.

Despite the initial excitment about using SP to identify CSCs, the ABCG2-highly expressing SP and ABCG2-negative non-SP tumor cells have been reported to be similarly tumorigenic (Patrawala et al., 2005). It is believed that the SP fraction obtained is not a pure stem-cell population, which is greatly affected by the isolation method (Montanaro et al., 2004). There were also report demonstrating that SP cells do not identify stem cell (Triel et al., 2004). Moreover, ABCG2, the molecular determinant for Hoechst exclusion, is not an absolute requirement for stem cells. Abcg2-deficient mice are viable and demonstrate no defect in steady state hematopoiesis, though the bone marrow of Abcg2-deficient mice does lack a SP (Zhou et al., 2002). Nevertheless, since CSCs lack distinct molecular markers, Hoechst 33342-dependent cell sorting remains the most widely employed technique for the identification and purification of putative CSCs.

It is also noteworthy that expression of drug transporters (especially MDR1/Pgp) can be part of the differentiated phenotype of cells in normal tissue (Triel et al., 2004). Histopathological and molecular biological studies have reported increased expression of ABCB1 in more differentiated tumors (Mizoguchi et al., 1990; Nishiyama et al., 1993; Bates et 
al., 1989; Mickley et al., 1989). We have also reported the cell type-specific upregulation of ABCG2 by romidepsin, a differentiating agent and anticancer drug, in cancer cell lines (To et al, 2008, 2011). Furthermore, P-gp and/or ABCG2 are usually overexpressed with the onset of multidrug resistance in cancer cell populations. In these situations, the SP phenotype will not definitively identify CSCs, but because the overexpression of these transporters allows the cells to effectively exclude the Hoechst dye.

\subsubsection{CSC-specific cell surface markers}

Another common way to identify putative CSCs from patient-derived tissues or cancer cell lines is by labeling the isolated cells with antibodies against various cell surface markers already known in normal stem cells. Cells bearing these cell-surface markers can be isolated by fluorescence activated cell sorting (FACS) (Woodward et al., 2005) or magnetic bead columns (Dou et al., 2007). These enriched cell populations are then tested for their ability to initiate tumorigenesis in immune deficient mice.

Several cell surface markers have been used to detect CSCs (Table 1). Among them, the cell surface protein CD133 (Prominin 1, a transmembrane glycoprotein) is probably the most extensively used marker, which was also known to define stem and progenitor cells in varuous tissues (Shmelkov et al., 2005). A cautionary technical note is worth mentioning. CD133 expression is in fact found to be indifferent to the differentiation status of most cells. On the other hand, its posttranslational glycoslyated form was found to be downregulated upon cell differentiation (Florek et al., 2005). Therefore, upon dedifferentation of the committed cells to generate CSCs as observed in oncogenesis (Figure 1), the glycosylation of CD133 (AC133, the glycosylated epitope of CD133) is expected to increase and therefore serve as a marker for the tumorigenic potential of putative CSCs. In other words, antibody against AC133, but not CD133, should be used for the prospective identification of putative CSCs. It is also noteworthy that, since tumor initiating CSCs are heterogeneous, a specific marker or set of markers has not been found to unequivocally identify CSCs in solid tumors (Welte et al., 2010). CSCs identified from solid tumors may also express other organ-specific markers.

\begin{tabular}{|c|c|c|}
\hline Tumor type & $\begin{array}{c}\text { Putative CSC cell surface } \\
\text { markers }\end{array}$ & Reference \\
\hline Breast & $\mathrm{CD} 44^{+} \mathrm{CD} 24-/ \mathrm{low}$ & $\begin{array}{c}\text { Al-Hajj et al. (2003); Wang et al. } \\
\text { (2010) }\end{array}$ \\
\hline Colon & $\mathrm{CD}_{133^{+}}$ & Fang et al. (2010) \\
\hline Colon & $\mathrm{CD}_{44^{+}}$EpCamhigh $^{\text {hD } 166^{+}}$ & Kanwar et al. (2010) \\
\hline CNS & $\mathrm{CD} 133^{+}$ & Pallini et al. (2011) \\
\hline HNSCC & $\mathrm{CD}_{4} 4^{+} \mathrm{ALDH}^{+}$ & Chen et al. (2010) \\
\hline Liver & $\mathrm{CD}_{13}{ }^{+}$ & Haraquchi et al. (2010) \\
\hline Melanoma & $\mathrm{CD} 20^{+}$ & Schmidt et al. (2011) \\
\hline $\begin{array}{l}\text { Multiple } \\
\text { myeloma }\end{array}$ & CD138- & Singh et al. (2004) \\
\hline NSCLC & $\mathrm{CD}_{133^{+}}$ & Salnikov et al. (2010) \\
\hline Pancreas & $\mathrm{CD}_{4} 4^{+} \mathrm{CD} 24^{+} \mathrm{ESA}^{+}$ & Hong et al. (2009) \\
\hline Prostate & $\mathrm{CD}_{4} 4^{+} \alpha 2 \beta 1^{+} \mathrm{CD} 133^{+}$ & Collins et al. (2005) \\
\hline
\end{tabular}

(HNSCC $=$ head and neck squamous cell carcinoma; NSCLC $=$ non small cell lung cancer)

Table 1. Commonly employed CSC cell surface markers in various tissues 


\subsubsection{Anchorage-independent sphere formation assay}

Putative CSCs have also been identified based on their ability to form colonies in vitro. Typically, putative CSCs fractions are seeded onto culture dishes coated with serum-free media containing epidermal growth factor and basic fibroblast growth factor. The growth of spherical colonies after a few weeks is considered indicative of self-renewal ability, and would be consistent with a CSC phenotype. Sphere-forming ability as a measure of stem cells was first developed for central nervous system (CNS) cells, where it has been shown that a subset of cells isolated from human fetal brain, and subsequently from human CNS tumors, can form spheres when cultured under the appropriate conditions (Tamaki et al., 2002). These spheres can self renew in vitro, and differentiate into all of the neuronal lineages, both in vitro and in vivo. More importantly, it was subsequently demonstrated for brain tumors that the neurosphere-forming cells could be prospectively isolated from fresh tissue using the cell surface marker CD133. These CD133+ cells did indeed initiate brain tumors in vivo, without any in vitro manipulation, indicating that they do in fact represent CSCs (Singh et al., 2003).

\subsection{CSCs in hematopoietic malignancies}

The hematopoietic system is the best characterized somatic tissue with respect to stem cell biology. Many of the physical, biologic, and developmental features of normal hematopoietic stem cells have been defined and useful methods for studying stem cells have been established. It is therefore not surprising that CSCs were first identified in human acute myelogenous leukemia (AML), an aggressive malignancy of immature hematopoietic cells in the bone marrow. The leukemia-initiating activity of primary human AML cells in immunodeficient mice was first demonstrated by John Dick \& colleagues, where they found that the "leukemic stem cells (LSCs)" were exclusively found in the CD34+CD38subpopulation (Bonnet \& Dick, 1997). As normal hematopoietic stem cells (HSC) share the CD34+CD38- immunophenotype, it was proposed that AML stem cells arise from HSC.

\subsection{CSCs in solid tumors and cancer cell lines}

CSCs have been more difficult to identify in non-haematopoietic cancers because fewer well-developed phenotypic markers and definitive assay systems are available. Al-Hajj et al. were the first to identify and prospectively isolate a minority subpopulation of cells from a human solid breast cancer cell line, based on the expression of surface markers and their potential to form tumor after injection into the mammary fat pad of NOD/SCID mice (Al-Hajj et al., 2003). Cells with the phenotype of epithelial-specific antigen (ESA)+ Lineage marker (Lin)-CD24-/lowCD44+ were found to generate tumor that were histologically similar to those of primary breast tumors in mice when as few as 100 cells were transplanted. Similar findings were also published for human brain tumors (GBMs and medulloblastomas) (Singh et al., 2003; Hemmati et al., 2003). These CSCs can differentiate into cells that have characteristics of both neurons and glial cels, self-renew in vitro at higher levels than normal neuronal stem cells, and grow and differentiate in neonatal rat brains. Interestingly, the putative CSCs isolated from these brain tumors overexpressing CD133 were found to regenerate identical brain tumors in NOD/SCID mice. Furthermore, these tumors could also be serially transplanted (Singh et al., 2004). It is likely that, as suitable markers and assay systems become available, more solid tumor CSCs will be described. 


\subsection{Signaling pathways supporting the self-renewal of CSCs}

There are several signaling pathways including Notch (McGovern et al., 2009), Wnt/ $\beta$ catenin (Reya \& Clevers, 2005), Hedgehog (Medina et al., 2009), and PI3K/Akt (Hu et al., 2005), which have known roles in maintenance and/or control of normal and cancer stem cell compartments, as well as being implicated in cancer. Since they are playing an important functional role in CSC self-renewal and survival, they also represent attractive novel therapeutic targets for complete eradication of tumor. A short list of candidate chemotherapeutic drugs designed to target these signaling pathways, currently under preclinical development or in clinical trials, is compiled in Table 2 and Table 3, respectively. Selected signaling cascades are also discussed in more detail as follows.

\begin{tabular}{|c|c|c|c|}
\hline Target & Novel agent/combination & $\begin{array}{l}\text { CSCs from specific } \\
\text { tumor type tested }\end{array}$ & Reference \\
\hline Bcl-2 & TRAIL + ABT-737 (Abbott) & Brain & $\begin{array}{l}\text { Tagscherer et } \\
\text { al., } 2008\end{array}$ \\
\hline CD44 & CD44 antibodies & AML & Jin et al., 2006 \\
\hline Death receptors & TRAIL + chemotherapy & AML progenitors & $\begin{array}{l}\text { Plasilova et } \\
\text { al., } 2002\end{array}$ \\
\hline $\begin{array}{c}\text { Fatty acid } \\
\text { synthase (F A } \\
\text { S) }\end{array}$ & Resveratrol & Breast & $\begin{array}{c}\text { Pandey et al., } \\
2010\end{array}$ \\
\hline Hedgehog & Cyclopamine & Medulloblastoma & $\begin{array}{l}\text { Berman et al., } \\
2002\end{array}$ \\
\hline IL-4 & $\begin{array}{c}\text { IL-4 blocking antibodies + } \\
\text { chemotherapy }\end{array}$ & Colon & $\begin{array}{c}\text { Francipane et } \\
\text { al., } 2008\end{array}$ \\
\hline Notch & $\gamma$-secretase inhibitor (GSI-18) & Medulloblastoma & Fan et al., 2006 \\
\hline PI3K/Akt & A-443654 (Abbott) & Brain & $\begin{array}{l}\text { Gallia et al., } \\
2009\end{array}$ \\
\hline $\mathrm{SHH} / \mathrm{mTOR}$ & $\begin{array}{c}\text { Cyclopamine }+ \text { rapamycin }+ \\
\text { chemotherapy }\end{array}$ & Pancreas & $\begin{array}{l}\text { Mueller et al., } \\
2009\end{array}$ \\
\hline TGF- $\beta$ & TGF- $\beta+$ imatinib & CML & $\begin{array}{l}\text { Naka et al., } \\
2010\end{array}$ \\
\hline $\begin{array}{c}\text { Wnt/ } \beta- \\
\text { catenin/lef-1 }\end{array}$ & $\begin{array}{c}\text { CGP049090, PKF115-584 } \\
\text { (Novartis) }\end{array}$ & CLL & $\begin{array}{c}\text { Gandhirajan et } \\
\text { al., } 2010\end{array}$ \\
\hline $\begin{array}{c}\text { Wnt } \\
\text { (Canonical) }\end{array}$ & $\begin{array}{c}\text { ZTM000990, PKF118-310, } \\
\text { anti-WNT1 \& anti-WNT2 } \\
\text { antibodies }\end{array}$ & -- & $\begin{array}{c}\text { Barker \& } \\
\text { Clevers, } 2006\end{array}$ \\
\hline XIAP & $\begin{array}{c}\text { Small molecular XIAP } \\
\text { inhibitors (Pfizer) }+\gamma- \\
\text { irradiation }\end{array}$ & Brain & $\begin{array}{c}\text { Vellanki et al., } \\
2009\end{array}$ \\
\hline
\end{tabular}

Table 2. Preclinical studies of novel drug candidates targeting various signaling pathways associated with CSCs. 


\begin{tabular}{|c|c|c|c|c|}
\hline Target & Drug & $\begin{array}{l}\text { Cancer type } \\
\text { (Phase) }\end{array}$ & Sponsor & $\begin{array}{c}\text { Clinical trial } \\
\text { identifier }\end{array}$ \\
\hline \multirow[t]{4}{*}{ Notch } & MK0752 & Breast (I) & Merck & NCT00106145 \\
\hline & & Pancreatic (I, II) & $\begin{array}{c}\text { Cancer } \\
\text { Research, UK }\end{array}$ & NCT01098344 \\
\hline & PF-03084014 & Leukemia (I) & $\begin{array}{l}\text { Pfizer } \\
\text { U Health }\end{array}$ & NCT00878189 \\
\hline & RO4929097 & Renal cell (II) & $\begin{array}{l}\text { Network, } \\
\text { Toronto }\end{array}$ & NCT01141569 \\
\hline \multirow[t]{5}{*}{$\begin{array}{c}\text { Sonic } \\
\text { Hedgehog }\end{array}$} & BMS-833923 & Basal cell (I) & $\begin{array}{l}\text { Bristol-Myers } \\
\text { Squibb }\end{array}$ & NCT00670189 \\
\hline & GDC-0449 & Solid tumors (I) & Genentech & NCT00968981 \\
\hline & & Colorectal (II) & Genentech & NCT00636610 \\
\hline & LDE225 & $\begin{array}{l}\text { Medulloblastoma } \\
\text { (I) }\end{array}$ & Novartis & NCT00880308 \\
\hline & PF-04449913 & Hematologic (I) & Pfizer & NCT00953758 \\
\hline Wnt & Resveratrol & Colon (I, II) & $\begin{array}{l}\text { U California, } \\
\text { Irvine }\end{array}$ & NCT00256334 \\
\hline
\end{tabular}

Table 3. Clinical trials on new drugs specifically targeting CSC signaling pathways.

\subsubsection{Notch}

The Notch/ $\gamma$-secretase/Jagged signaling pathway is involved in cellular response to intrinsic or extrinsic developmental cues to execute specific developmental programs (Artavanis-Tsakonas et al., 1999). It is an important regulator of differentiation and helps control cell fate. It is also involved in vasculogenesis and angiogenesis. Extensive crosstalk has been shown to exist between Notch and other developmental signaling pathways (Hedgehog and Wnt, see below). Notch signaling is activated by ligand binding. The Notch ligands (Jagged $1 \&$ 2, and Delta 1-3) induce the release of the Notch intracellular (Notch-IC) domain via enzymatic cleavage by $\alpha$ - and $\gamma$-secretases. The released Notch-IC will then translocate to the nucleus where it turns on the transcription of Notch responsive genes (Artavanis-Tsakonas et al., 1999; Lehar et al., 2005). Notch signaling pathways are activated in both breast CSCs (Phillips et al., 2006) and in endothelial cells (Scharpfenecker et al., 2009) in response to radiation. $\gamma$-secretase inhibitors have been developed to inhibit Notch signaling to block CSC self-renewal and were shown to inhibit the engraftment of medulloblastoma in animal model (Fan et al., 2006).

\subsubsection{Wnt/ $\beta$-catenin}

The Wnt signaling pathway is an ancient system that has been highly conserved during evolution. It has been implicated in a wide range of biological processes from maintaining stem cells in their pluripotent state to the induction of specific tissues and organs during development. Canonical Wnt signals are transduced through Frizzled family receptors and LRP5/LRP6 coreceptor to the $\beta$-catenin signaling cascade (comprehensively reviewed by Wend et al., 2010). This Wnt/ $\beta$-catenin signaling pathway is important for self-renewal in stem cells and has been found to be dysregulated in solid and haematopoietic cancers (Zhao et al., 2007; Katoh \& Katoh, 2007). The pathway has also been shown to promote genomic instability, thereby enhancing the DNA damage tolerance in CSCs (Eyler \& Rich, 2008). 
Conditional knockout of the key Wnt mediator protein $\beta$-catenin in hematopoietic progenitor cells have been shown to delay the development of CML in a bone marrow transplantation model in mice (Zhao et al., 2007).

\subsubsection{Sonic hedgehog (SHH)}

The SHH pathway is regulated by the binding of Shh (ligand) on the transmembrane receptor patched (Ptch). In the absence of Shh, Ptch inhibits the activity of another transmembrane protein, smoothened (Smo), resulting in inactivation of the $\mathrm{SHH}$ pathway (Pasca di Magliano et al., 2003). Binding of Shh to Ptch abrogates the inhibitory effect of Ptch. Smo is derepressed and the transcription factor Gli (Gli1-3) is activated. Gli1 is a potent activator of a number of downstream target genes, including HNF-3 $\beta$, cyclins D1, IGFBP-6, Snail, CXCR4, and Bcl-2, to regulate neural development, cell proliferation, oncogenesis, survival, epithelial-mesenchymal transition, migration, invasion and metastasis, respectively (Katoh \& Katoh, 2007). As positive and negative feedbacks, GLI1 protein respectively activates its own expression and that of PTCH1 (Agren et al., 2004). Therefore, Gli1 is considered a marker of abnormal activation of $\mathrm{SHH}$ pathway. While both $\mathrm{SHH}$ and Wnt pathways are commonly hyperactivated in tumors to sustain tumor growth, crosstalk between the two pathways has been reported (He et al., 2006), which adds to the complexity of regulation of CSCs. With the development of specific $\mathrm{SHH}$ inhibitors such as cyclopamine, the $\mathrm{SHH}$ signaling pathway has been proposed to be a druggable target in CSCs (Medina et al., 2009).

\subsubsection{PI3K/PTEN/Akt}

The PI3K/PTEN/Akt pathway is one of the most extensively studied signal transduction axes that control cell growth, survival, and proliferation (Sarker et al., 2009). The loss of PTEN and the consequent enhancement of Akt pathway activity has been found to constitute the major molecular events accompanying the increased stem cell character and chemoresistance of gliomas (Hu et al., 2005). Activate Akt pathway is also associated with the occurrence of a population of radiation resistant cancer stem-like cells in medulloblastomas, where Akt inhibition appears to sensitize the cells for radiation-induced apoptosis (Hambardzumyan et al., 2008).

With a better appreciation of the CSC-specific signaling pathways, it becomes logical in an attempt to eradicate the tumor by combining these CSC-targeted therapies with standard chemotherapies. Since the aforementioned pathways also govern normal stem cell development and maintenance, it will be critical to establish a dose and schedule where the tumor is suppressed or eliminated without undue toxicity of normal stem cells. Recent data on mouse leukemia models suggest that the PTEN-dependence of CSCs may be exploited for their specific targeting, while sparing the normal haematopoietic stem cells (Yilmaz et al., 2006). Rapamycin was found to selectively kill the leukemia initiating cells in mice harboring a conditional deletion of PTEN, illustrating that novel therapies may be devised specifically for CSCs.

\section{Multidrug resistance and cancer stem cells}

\subsection{Working models of cancer drug resistance}

Clinical drug resistance to anticancer therapy is well-known to be multifactorial, involving alteration in drug targets, inactivation of drug, decreased drug uptake, increased drug 
efflux, and dysregulation of apoptosis pathways (Gottesman, 2002). Usually, cancers that recur after an initial response to chemotherapeutic drugs become resistant to multiple drugs, giving rise to the phenomenon of multidrug resistance (MDR). The traditional belief is that a few cells in the tumor have acquired genetic alteration(s) to confer drug resistance (i.e. "clonal evoluation" model, Figure 3A). These resistant clones have a selective advantage that enables them to outgrow the rest of the tumor following chemotherapy.

A

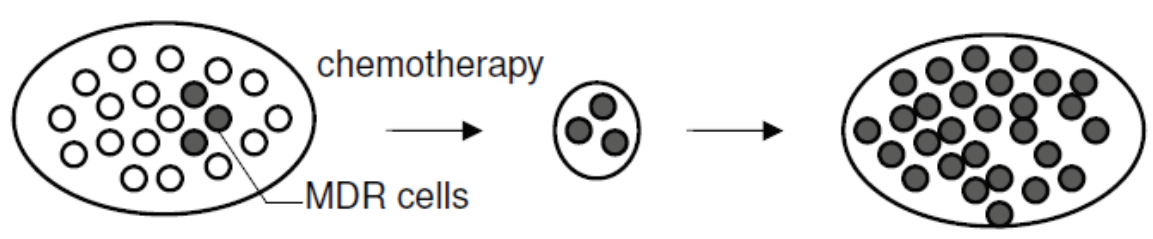

B

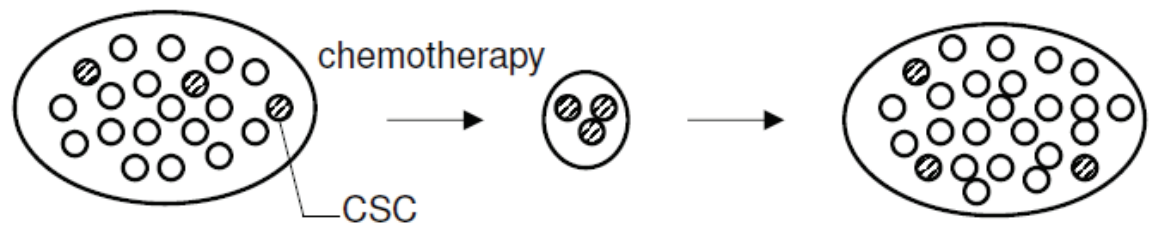

C

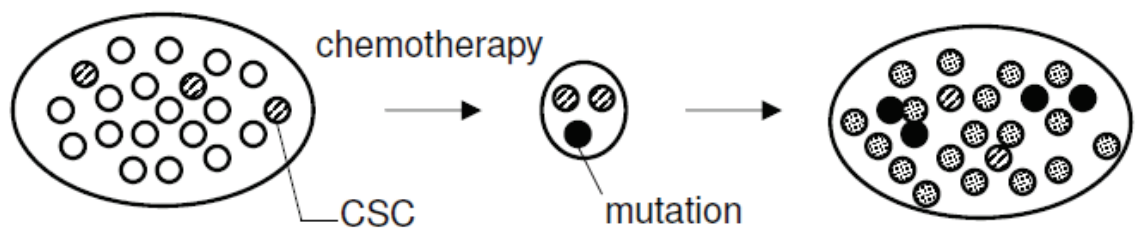

A. Conventional model of cancer drug resistance: A few resistant clones (MDR cells) have acquired drug resistance through genetic alterations. Following chemotherapy, these drug resistant clones survive and give rise to a tumor made up of their progeny cells.

B. CSC model of cancer drug resistance: The original tumor contains a small population of CSCs and their more differentiated progeny. Following chemotherapy, only the CSCs survive by their innate protective mechanisms. Thereafter, they can repopulate the tumor by asymmetrical cell division (i.e. giving rise to another CSC and a differentiated progeny originated from the CSC).

C. "Acquired resistance" CSC model of cancer drug resistance: The original tumor contains a small population of CSCs and their more differentiated progeny. Following chemotherapy, while only the CSCs survive, some of them acquire mutations that confer a high level of drug resistance.

Fig. 3. Models of cancer drug resistance 
With better appreciation of the role of CSCs in cancer biology, MDR is generally considered to be ultimately caused by CSCs. As discussed above, CSCs share many properties of the normal stem cells, which help protect them from cytotoxic insult throughout their long lifespan. These properties include quiescence, resistance to xenobiotics through the expression of several ATP-binding cassette $(\mathrm{ABC})$ transporters, active DNA repair capacity, and resistance to apoptosis, which collectively make CSCs naturally resistant to chemotherapy. Therefore, after exposure to conventional chemotherapeutic drugs, CSCs survive and are able to repopulate the tumor both with another CSC and with differentiated cells originated from the CSCs (Figure 3B).

This working model where the intrinsic protective mechanisms of CSCs alone provide the basis for drug resistance might be considered too simplistic. A modified "acquired resistance" stem-cell model was thus proposed to more closely resemble the real clinical situation (Figure 3C). This can be exemplified in the recent studies of imatinib resistance in leukemia patients. Imatinib, a tyrosine kinase inhibitor, is a promising molecularly targeted chemotherapeutic agent. It has been shown to be both a substrate and inhibitor of ABCG2, thus allowing its efflux by a stem cell that express this ABC transporter (Houghton et al., 2004; Burger et al., 2004). In-depth mechanistic studies in imatinib-resistant leukemia cells revealed several "acquired" mutations in the kinase domain of ABL in patient with CML or with AML associated with $t(9 ; 22)(q 34 ; q 11)$. These findings therefore suggest that CSCs expressing the drug transporter could facilitate, but not be solely responsible for, the acquisition of acquired mechanisms of drug resistance. As for imatinib, the acquired mutation in $\mathrm{ABL}$, the ultimate drug target, could confer higher levels of drug resistance.

Different tumor types may respond differently to chemotherapy. Cancers that respond to initial chemotherapy may appear to acquire drug resistance during the course of treatment. Other cancers may appear to be intrinsically resistant. In either case, the CSC model of drug resistance applies. It is the quiescent CSCs with the innate drug resistance that survive the chemotherapy; and more importantly, they are capable of repopulating the tumor following chemotherapy. On the other hand, acquired drug resistance in more differentiated cancer cells, through gene mutation, amplification or rearrangement, may contribute to an aggressive phenotype, but it is not the primary reason for cancer recurrence or spread after therapy. Therapeutic strategies that specifically target the CSCs should eradicate tumors more effectively than current treatments and reduce the risk of relapse and metastasis.

\subsection{ABC Transporters and normal stem cells/CSCs}

Among the several protective mechanisms for CSCs, the overexpression of the ATP-binding cassette $(\mathrm{ABC})$ efflux transporters is probably the most important. The $\mathrm{ABC}$ transporters belong to the largest superfamily of transport proteins (Gottesman \& Ambudkar, 2001). A total of $49 \mathrm{ABC}$ transporter genes have been identified in the human genome and they were grouped into seven subfamilies (designated A to $G$ ) according to their structural and sequence homologues (Vasiliou et al., 2009). By using the energy of ATP hydrolysis, these transporters actively efflux drugs from cells, serving to protect them from cytotoxic substances. The two $\mathrm{ABC}$ transporter-encoding genes that have been studied most extensively in stem cells are $A B C B 1$ (MDR1), which encodes P-glycoprotein, and ABCG2. Together with $A B C C 1$ (MRP1), they represent the three major multidrug resistance genes that have been identified in cancer cells. Table 4 summarizes the different $A B C$ transporters that have been found to contribute to cancer drug resistance. 


\begin{tabular}{|c|c|c|c|c|}
\hline Gene & Protein / alias & $\begin{array}{l}\text { Location on } \\
\text { chromosome }\end{array}$ & $\begin{array}{l}\text { Chemotherapeutic } \\
\text { drugs effluxed }\end{array}$ & $\begin{array}{c}\text { Other important } \\
\text { substrates }\end{array}$ \\
\hline$A B C A 2$ & ABCA2 & $9 q 34.3$ & estramustine & - \\
\hline$A B C A 3$ & ABCA3 & $16 \mathrm{p} 13.3$ & daunorubicin & surfactant? \\
\hline$A B C B 1$ & $\begin{array}{l}\text { P-gp/ } \\
\text { MDR1 }\end{array}$ & 7q21.12 & $\begin{array}{c}\text { colchicine, doxorubicin, } \\
\text { etoposide, vinblastine, } \\
\text { paclitaxel }\end{array}$ & $\begin{array}{l}\text { digoxin, } \\
\text { saquinivir, } \\
\text { rhodamine }\end{array}$ \\
\hline$A B C B 4$ & MDR3 & $7 q 21.12$ & paclitaxel, vinblastine & bile salt \\
\hline$A B C B 5$ & ABC19 & $7 \mathrm{p} 15.3$ & doxorubicin & - \\
\hline$A B C B 11$ & BSEP/SPGP & $2 q 21.3$ & paclitaxel, vinblastine & $\begin{array}{l}\text { bile salt, } \\
\text { pravastatin }\end{array}$ \\
\hline$A B C C 2$ & MRP2 & 16p13.12 & $\begin{array}{c}\text { doxorubicin, } \\
\text { daunorubicin, } \\
\text { vincristine, etoposide, } \\
\text { colchicine, } \\
\text { camptothecins, } \\
\text { methotrexate } \\
\text { vinblastine, cisplatin, } \\
\text { doxorubicin, } \\
\text { methotrexate }\end{array}$ & $\begin{array}{l}\text { sulfinpyrazone, } \\
\text { bilirubin }\end{array}$ \\
\hline$A B C C 3$ & MRP3 & $17 q 21.33$ & $\begin{array}{l}\text { methotrexate, etoposide } \\
\text { 6-mercaptopurine, 6- }\end{array}$ & - \\
\hline$A B C C 4$ & MRP4 & $13 q 32.1$ & $\begin{array}{l}\text { thioguanine, } \\
\text { methotrexate }\end{array}$ & cAMP, cGMP \\
\hline$A B C C 5$ & MRP5 & $3 q 27.1$ & $\begin{array}{c}\text { 6-mercaptopurine, 6- } \\
\text { thioguanine, }\end{array}$ & cAMP, cGMP \\
\hline ABCC6 & MRP6 & $16 \mathrm{p} 13.12$ & etoposide & - \\
\hline$A B C C 10$ & MRP7 & 6 p21.1 & paciltaxel & $E_{2} 17 \beta G$ \\
\hline$A B C C 11$ & MRP8 & $16 q 12.1$ & $\begin{array}{l}\text { 5-fluorouracil } \\
\text { mitoxantrone, }\end{array}$ & cAMP, cGMP \\
\hline ABCG2 & ABCG2/BCRP & $4 q 22$ & $\begin{array}{l}\text { topotecan, doxorubicin, } \\
\text { daunorubicin, } \\
\text { irinotecan, imatinib, } \\
\text { methotrexate }\end{array}$ & $\begin{array}{c}\text { pheophorbide A, } \\
\text { Hoechst 33342, } \\
\text { rhodamine }\end{array}$ \\
\hline
\end{tabular}

Table 4. ABC transporters involved in drug resistance

\subsubsection{ABCB1}

ABCB1, also commonly known as P-glycoprotein (P-gp), is the most extensively studied multidrug resistance transporter, which was discovered more than 30 years ago (Jiliano \& Ling, 1976). It has been found to be expressed in $>50 \%$ of all drug-resistant tumors. Human ABCB1 is the product of the MDR1 gene and acts as an ATP-dependent pump for a multitude of structurally unrelated hydrophobic compounds, including numerous anticancer and antimicrobial drugs (Gottesman \& Ambudkar, 2001).

In Hoechst dye exclusion assay using human cancer cell lines, the expression of ABCB1 (usually together with ABCG2) has been found to be higher in the isolated SP cells. As described above, the SP population has an enhanced capacity for the efflux of Hoechst dye, 
presumably due to ABCB1 and/or ABCG2 expression. Although Zhou et al. reported that $\mathrm{ABCB} 1$ may not contribute to the SP phenotype because bone marrow cells from $\mathrm{Mdr} 1 \mathrm{a} / 1 \mathrm{~b}^{-/-}$ mice are completely lacking in the SP population (Zhou et al., 2001), ABCB1 is still generally considered to be important in protecting CSCs from toxic insult. Result by Zhou et al. may just represent a tumor type-specific observation. Moreover, SP indeed does not define CSCs. The SP fraction is composed of both stem and non-stem cells, and some stem cells are not located in the SP compartment (Zhou et al., 2002).

\subsubsection{ABCG2}

ABCG2 is a more recently discovered $A B C$ transporter responsible for cancer drug resistance. It was discovered almost simultaneously by three research groups, giving it three different names (BCRP/ABCP/MXR) in the 1990s (Doyle et al., 1998, Allikmets et al., 1998; Miyake et al., 1999). Subsequently, the sequences for these genes turned out to be nearly identical, thereafter the gene was assigned an official name $A B C G 2$ by the Human Gene Nomenclature Committee, which falls into the " $G$ " subfamily of $A B C$ transporters comprising only of half-transporters.

The list of ABCG2 substrates has been expanding rapidly, which highlights the important role of this transporter in drug disposition and treatment outcomes (Polgar et al., 2008). Numerous cancer chemotherapeutic drugs have been identified as ABCG2 substrates, such as mitoxantrone, flavopiridol, topotecan, and some of the newly developed tyrosine kinase inhibitors. There is considerable overlap in substrate drug specificity of ABCG2 and other multidrug resistance transporters, including $\mathrm{ABCB} 1, \mathrm{ABCC} 1, \mathrm{ABCC} 2$, and some solute carrier transporters. Besides anticancer drugs, several other therapeutic classes have also been described as ABCG2 substrates, including antibiotics, antivirals, flavonoids, and antihyperlipidemic drugs.

Numerous studies have indicated that ABCG2 overexpression plays a possible role in cancer drug resistance, particularly in leukemia (Ross et al., 2010). For example, higher expression of ABCG2 was found to be associated with AML cases (Ross et al., 2000) or with a poor response to remission induction therapy in AML cases (Steinbach et al., 2002). Of note, ABCG2 is often found to be expressed together with P-gp in AML cases, resulting in poor prognosis (Galimberti et al., 2004; van den Heuvel-Eibrink et al., 2007). Interestingly, ABCG2 and ABCB1 mRNA level was found to be higher in non-responding AML cases, only when the primitive subset of CD34+/CD38- leukaemia stem cells were analyzed (Ho et al., 2008). Although the self renewal capability was not evaluated for the CD34+/CD38- cell population in these studies, it appears that they are the tumor-initiating CSCs protected by the increased expression of the transporters.

\subsubsection{Physiological role of $A B C B 1$ and $A B C G 2$ in CSCs}

Although high expression of $A B C B 1$ and ABCG2 is generally believed to be a marker for normal and/or cancer stem cells, their physiological role in still not clear. Mice deficient in either Abcb1, Abcc1, or Abcg2 are viable, fertile and have normal stem cell compartments (Schinkel et al., 1994; Zhou et al., 2002; Jonker al., 2002). This indicates that none of these transporter genes are necessary for stem cell growth or maintenance. On the other hand, these knockout mice are more sensitive to the effects of drugs such as vinblastine, ivermectin, topotecan and mitoxantrone, consistent with a role for these $\mathrm{ABC}$ transporters in protecting cells from toxins. 
As discussed above, both ABCB1 and ABCG2 have been proposed to be survival factors for normal stem cells or CSCs by excluding various xenotoxins out of the cells. However and interestingly, ABCB1/P-gp expression generally tracks with the cell differentiation status, where more differentiated tumors tend to have higher expression of the transporter (Mizoguchi et al., 1990; Nishiyama et al, 1993). Moreover, ABCB1/P-gp expression is almost universally found to be upregulated, accompanied by increased expression of markers of maturation, in cancer cell lines treated with differentiating agents (Bates et al., 1989; Mickley et al., 1989). Given that CSCs need to maintain their pluripotent state for self-renewal and repopulating the rest of the tumor, they should be minimally differentiated. It follows that ABCB1/P-gp may not be an important CSC survival factor per se. In contrast, high level functional expression of ABCG2 has been reported in undifferentiated human embryonic stem cells (hESCs) (Apati et al., 2008). The therapeutic implication of these observations is that the undifferentiated and ABCG2-overexpressing cancer cells within a tumor may represent the most chemoresistant putative CSCs that need to be targeted for complete eradication of the tumor.

\subsubsection{Overcoming drug resistance by transporter inhibition}

\subsubsection{Early generations of transporter inhibitors}

An obvious strategy to restore drug sensitivity in MDR cancer cells caused by ABC drug transporters is to block transporter-mediated drug efflux. Over the past decade, tremendous efforts have been made to discover and synthesize such inhibitors/modulators. Of note, efforts to combat drug resistance caused by the MDR transporters have focused mostly on the use of functional modulators or reversal agents, rather than modulation of the transporter gene regulation. The most well-known inhibitors that have been tested for targeting ABCB1/P-gp (verapamil, cyclosporine A, and valspodar (PSC833)) and ABCG2 (fumitremorgin C (FTC) and Ko143) are also useful research tools for studying modulation of these transporters. A few of these inhibitors, including tariquidar (XR9576) (Kuhnle et al., 2009), can interact with both ABCB1/P-gp and ABCG2. They represent promising lead compounds for further development because drug-resistant tumors usually have overexpression of more than one MDR transporters.

Numerous clinical trials have been performed to evaluate the combination of P-gp modulators with standard chemotherapy regimens in enhancing anticancer efficacy (Sandor et al., 1998). However, they were mostly disappointing and failed to prove the MDR reversal hypothesis, partly because of the lack of specific and potent inhibitors against the MDR transporters. On the other hand, unpredictable pharmacokinetic drug interactions, simultaneous involvement of several drug transporters in tumor tissues, as well as the variability in drug transporter expression levels among individuals, remain obstacles to using modulators to restore drug sensitivity in the clinic.

\subsubsection{Novel transporter inhibitors may hold promise to target CSCs}

The abrupt termination of a phase III clinical trial of a second generation ABCB1/P-gp inhibitor, valspodar (also known as PSC833), due to unexpected toxicity to the patients probably have an enormous negative impact in the field. It was just until recently when the discovery of potent and specific inhibition of P-gp and/or ABCG2 by tyrosine kinase inhibitors (TKIs) has renewed the research interest in developing drug transporter inhibitors for the circumvention of MDR. TKIs are an important new class of molecularly targeted 
chemotherapeutic agents that specifically inhibit several oncogenic tyrosine kinases, thereby regulating cancer proliferation, invasion, metastasis and angiogenesis. The first TKI that was approved for CML, imatinib, has been shown to reverse MDR by inhibiting ABCB1(Pgp) (Hegedus et al., 2002) and ABCG2 (Houghton et al., 2004). A few other TKIs were also demonstrated to reverse drug resistance mediated by MDR transporters in various in vitro and in vivo models (reviewed in Wang \& Fu, 2010). However, it is still controversial as to whether TKIs are substrates or inhibitors of ABCB1 (P-gp) and/or ABCG2, which may depend on the concentration used. Moreover, since these TKIs are acting on oncogenic tyrosine kinases, which may have interactions/crosstalk with the other CSC-specific signaling pathways described before, the novel TKIs may prove to be good drug candidates targeting CSCs.

Given the central role played by ABCB1 and/or ABCG2 in protecting CSCs, specific transporter inhibitors theoretically could be employed as "cancer stem cell sensitizing agents" that allow the most crucial and drug resistant cells in a tumor to be destroyed. These therapies would be predicted to have toxic effects on the patients' normal stem cells. Since both ABCG2 and ABCB1 are also known to constitute the blood-brain barrier, this approach has to be carefully titrated to avoid excessive toxicity.

\section{Regulation of MDR transporters and its relevance to CSCs}

As mentioned above, the MDR transporter ABCG2 may be the bona fide CSC survival factor. Therefore, our discussion in this section will focus on ABCG2. Recently, an increasing number of studies have focused on unravelling the molecular regulation of ABCG2 because ABCG2 expression is highly sensitive to various developmental and environmental stimuli.

\subsection{Transcriptional regulation of $A B C G 2$ at the promoter level}

Early studies examining the regulation of ABCG2 have focused at the transcriptional level. A few functional cis-elements have been identified at the ABCG2 promoter, including hypoxia (Krishnamurthy et al., 2004), estrogen (Ee et al., 2004), progesterone (Wang et al., 2008), and the xenobiotic (aryl hydrocarbon receptor) response elements (Tan et al., 2010; To et al., 2011), which tightly control ABCG2 expression and serve as cellular defense mechanisms against various stimuli. A PPAR- $\gamma$ response element upstream of the ABCG2 gene has also been shown to facilitate the upregulation of ABCG2 for protecting dendritic cells (Szatmari et al., 2006). Cytokines and growth factors have also been reported to affect ABCG2 levels, though the exact mechanism is not clear.

Other studies on ABCG2 regulation are mostly related to its overexpression in drugresistant cancer cell lines. The overexpression of ABCG2 has been found to correlate with increased binding of a set of permissive histone modification marks, RNA polymerase II and a chromatin remodelling factor Brg-1, but decreased association of a repressive histone mark, HDAC-1 and Sp1 with the proximal ABCG2 promoter (To et al., 2008a). It has been demonstrated that chromatin dynamics and structure contribute significantly to the maintenance of pluripotency and regulation of differentiation in embryonic stem cells (Shafa et al., 2010). To this end, prolonged drug selection has been found to enrich the resulting subline with CSC characteristics (Calcagno et al., 2010). Therefore, we speculate that the chromatin remodelling observed at the $A B C G 2$ promoter may coincide with the enrichment of the pluripotent CSCs in the drug-selected resistant cells (Figure 4). 

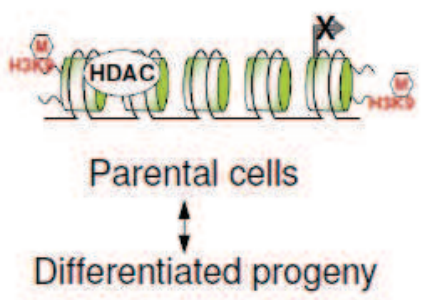

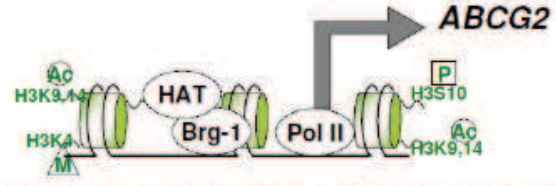

Drug resistant $A B C G 2$-overexpressing subline

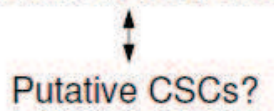

Fig. 4. Chromatin remodelling at the ABCG2 promoter allows overexpression of the transporter in drug-selected resistant cells (To et al., 2008a).

A closer look at the $A B C G 2$ promoter also reveal that there are a few putative binding sites for the stem cell transcription factors Oct4 and Nanog (Figure 5), which are known to promote self-renewal and pluripotency (Boyer et al., 2005). To this end, ABCG2 and Oct4/POU5F1 were found to be highly coexpressed in the resistant subline selected from the parental K562 leukemia cells (Marques et al., 2010). These observations are therefore consistent with the notion that ABCG2 is a survival factor for the pluripotent CSCs.

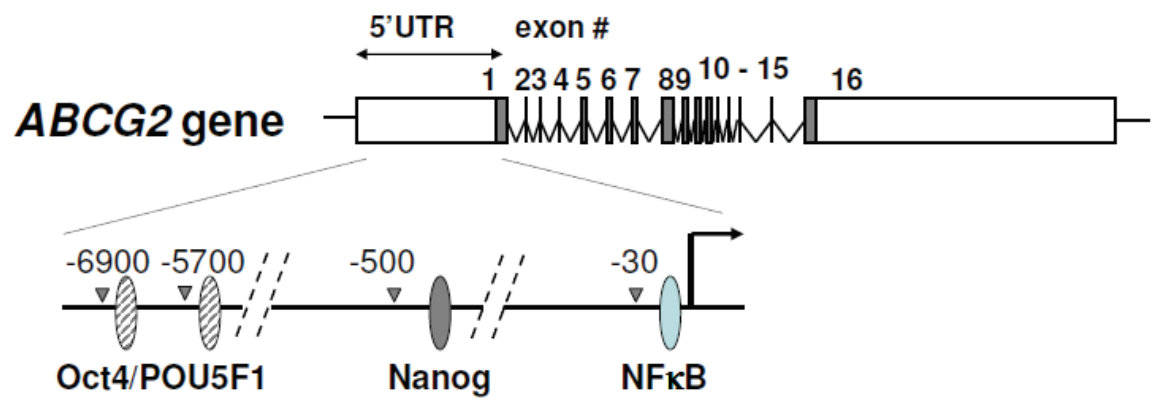

Fig. 5. Putative binding sites for the stem cell transcription factors Oct4 and Nanog at the ABCG2 promoter.

\subsection{MicroRNA-mediated regulation of ABCG2}

MicroRNAs (miRNAs) are small noncoding RNAs that repress gene expression in a variety of eukaryotic organisms. They play important roles in several cellular processes, such as proliferation, differentiation, apoptosis, and development, by simultaneously controlling the expression levels of hundred of genes. In human cancer, recent studies have shown that miRNA expression profiles differ between normal tissues and derived cancers and between cancer types ( $\mathrm{Lu}$ et al., 2005). MiRNAs can also act as oncogenes or tumor suppressors, exerting a key function in tumorigenesis (Esquela-Kerscher et al., 2006; Hammond, 2007). Gene regulation by miRNAs is mediated by the formation of imperfect hybrids with the 3'untranslated region ( $3^{\prime} \mathrm{UTR}$ ) sequences of the target mRNAs, leading to mRNA degradation and/or translational inhibition.

Evidence pointing to the role of miRNAs in determining drug sensitivity and MDR is emerging. First, miRNA expression is largely dysregulated in drug-resistant cancer cells 
(Zhu et al., 2008; Pan et al., 2009). Second, the miRNA expression patterns in the NCI-60 drug screen cell lines are significantly correlated to the sensitivity patterns of the cancer cells for a large set of anticancer agents (Blower et al., 2008). Third, numerous miRNAs have been found to regulate drug resistance genes such as DHFR (Mishra et al., 2007) and BCL2 (Xia et al., 2008).

We and others have independently identified three miRNAs (miR-519c, $-520 \mathrm{~h}$, and -328) regulating ABCG2 expression and determining the sensitivity of cancer cells (To et al., 2008b \& 2009; Liao et al., 2008; Wang et al., 2010; Pan et al., 2009, respectively). We reported that ABCG2 mRNA is more stable in drug-selected and ABCG2-overexpressing resistant cell lines than in their parental counterparts (To et al., 2008b \& 2009). This increase in mRNA stability was tied to a missing miR-519c binding site (also miR-328) in the truncated 3'UTR of ABCG2 mRNA in drug resistant cells (Figure 6). Intriguingly, the truncation of the ABCG2 3'UTR has also been reported in an undifferentiated human embryonic stem (HuES) cell line where its high ABCG2 expression was associated with the short 3'UTR variant forms (Apati et al., 2008). In contrast, another differentiated HuES cell line with lower ABCG2 levels possesses a longer 3'UTR variant (Apati et al., 2008). Sandberg et al. also found that rapidly proliferating cells express ABCG2 mRNA with shorter 3'UTRs, presumably to escape miRNA regulation (Sandberg et al., 2008). Therefore, in the resistant cells, miR-328 and miR-519c (though a proximal miR-519c binding site present also in the truncated 3'UTR has been recently discovered ( $\mathrm{Li}$ et al., 2011)) cannot bind to ABCG2 mRNA because of the shorter 3'UTR, and thus miRNA-mediated mRNA degradation and/or protein translation block are relieved, contributing to ABCG2 overexpression (Figure 6). In a human retinoblastoma cell line model, it has been further demonstrated that low expressions of all three miRNAs (miR-328, -519c, \& $-520 \mathrm{~h}$ ) correlate very well with high ABCG2 expression, with concomitant expression of other stem cell markers including CD133 and ALDH1A1 (Li et al., 2011). On the other hand, hsa-miR-520h has been reported to promote differentiation of hematopoietic stem cells by inhibiting ABCG2 expression (Liao et al., 2008). These findings collectively support an important role played by miRNAs in maintaining high ABCG2 level in CSCs. It will be interesting to verify if the same phenomenon is also observed in patient tumor samples.

The regulation of the other two major multidrug resistance transporters, Pglycoprotein/MDR1 and MRP1, by miR-451, -27a and -326, respectively, have also been reported (Kovalchuk et al., 2008; Li et al., 2010; Liang et al., 2010). More importantly, modulation of miRNA expression or function can alter sensitivity of cancer cells to anticancer drugs (Zhu et al., 2008; Pan et al., 2009; Blower et al., 2008). This could be achieved by inhibiting the function of up-regulated miRNAs or restoring the expression of down-regulated miRNAs. Together, miRNAs may represent important players in intrinsic or acquired MDR in cancer cells.

With the general appreciation of the importance of miRNAs in gene regulation, an emerging role of miRNAs in regulating stem cell self-renewal and differentiation has been revealed (Kashyap et al., 2009), which are important for proper stem cell function and maintenance. Recently, the coordinated regulation of miRNAs and various stem cell transcription factors including OCT4, SOX2 and Nanog have emerged as the master regulatory mechanism for stem cells pluripotency and differentiation. Given that ABCG2 could be downstream target of these stem cell transcription factors, it remains to be seen if the miRNA/stem cell transcription factors network could intercept with the regulation of the MDR transporters in contributing to the pluripotent state and chemoresistance of the CSCs. 


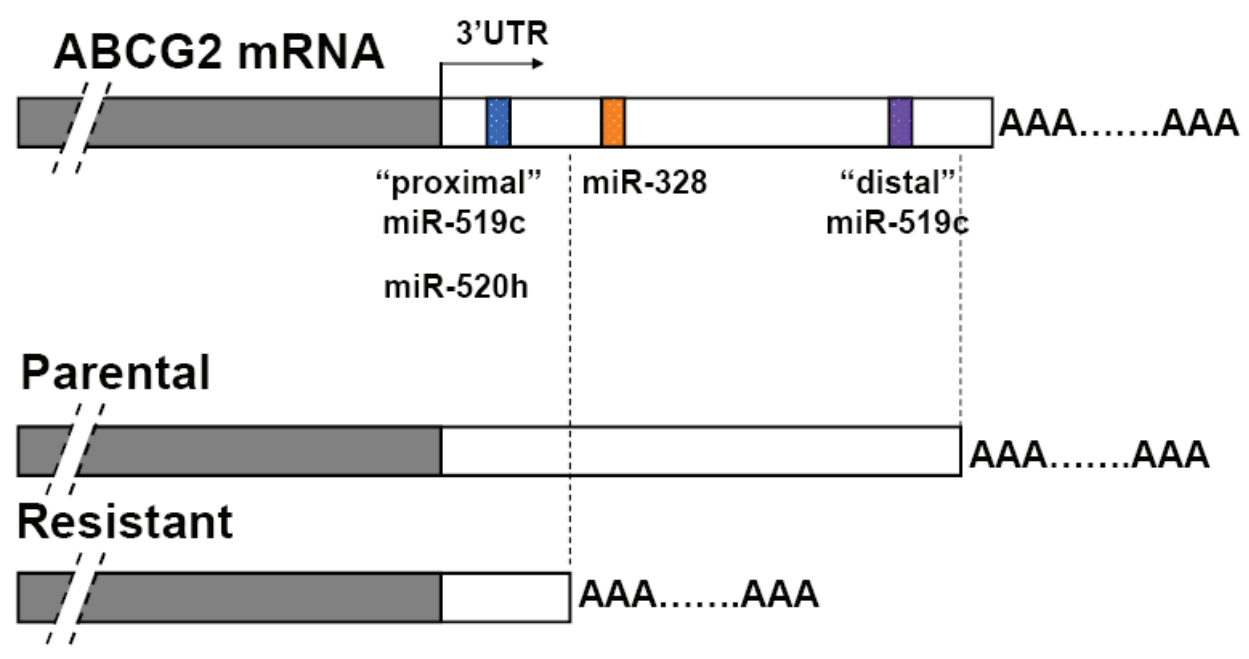

Fig. 6. A proposed model for ABCG2 upregulation in drug-resistant cells by escaping miRNA repression (To et al., 2009; Li et al., 2011)

\section{Conclusion}

The CSC model of drug resistance offers an appealing explanation as to why cancers that show an apparent complete clinical response to chemotherapy can relapse months or even years later. Numerous novel strategies to circumvent multidrug resistance have been designed to target the putative CSCs by exploiting pathways involved in MDR transportersmediated drug resistance, or forcing these cells to proliferate and differentiate thus converting them into a target of conventional therapies. Given the complicated microRNA/pluripotency transcription factor/MDR transporters/CSCs network described above, a better understanding of the various molecular mechanisms regulating pluripotency is pivotal to realizing the therapeutic potential of the novel treatment modalities.

\section{Acknowledgment}

We acknowledge the researchers who have contributed to the advancements in cancer stem cells and ABC transporter research and whose works have not been cited here because of space limitations. The work described in this chapter was supported in part by a grant from the NSFC/RGC Joint Research Scheme sponsored by the Research Grants Council of Hong Kong and the National Natural Science Foundation of China (Project No. N_CUHK443/10) and the Seed Research Funding provided by the School of Pharmacy (CUHK) to Kenneth To.

\section{References}

Agren, M.; Kogerman, P.; Lleman, M.I.; Wessling, M. \& Toftgard, R. (2004). Expression of the PTCH1 tumor suppressor gene is regulated by alternative promoters and a single functional Gli-binding site. Gene, Vol.330, (April 2004), pp.101-114. 
Al-Hajj, M.; Wicha, M.S.; Benito-Hernandez, A.; Morrison, S.J. \& Clarke, M.F. (2003). Prospective identification of tumorigenic breast cancer cells. Proc Natl Acad Sci USA, Vol.100, No.7, (April 2003), pp.3983-3988.

Allikmets, R.; Schriml, L.M.; Hutchinson, A.; Romano-Spica, V. \& Dean, M. (1998). A human placenta-specific ATP-binding cassette gene (ABCP) on chromosome 4q22 that is involved in multidrug resistance. Cancer Res, Vol.58, No.23, (December 1998), pp.5337-5339.

Alvi, A.J.; Clayton, H.; Joshi, C.; Enver, T.; Ashworth, A.; Vivanco, M.M., Dale, T.C. \& Smalley, M.J. (2003). Functional and molecular characterisation of mammary side population cells. Breast Cancer Res, Vol.5, No.1, (October 2002), pp.R1-R8.

Apati, A.; Orban, T.I.; Varga, N.; Nemeth, A.; Schamberger, A.; Krizsik, V.; Erdelyi-Belle, B.; Homolya, L.; Varady, G.; Padanyi, R.; Karaszi, E.; Kemna, E.; Nemet, K. \& Sarkadi, B. (2008). High level functional expression of the ABCG2 multidrug transporter in undifferentiated human embryonic stem cells. Biochim Biophy Acta, Vol.1778, No.12, (December 2008), pp.2700-2709.

Artavanis-Tsakonas, S.; Rand, M.D. \& Lake, R.J. (1999). Notch signaling: cell fate control and signal integration in development. Science, Vol.284, No.5415, (April 1999), pp.770776.

Asakura, A. \& Rudnicki, M.A. (2002). Side population cells from diverse adult tissues are capable of in vitro hematopoietic differentiation. Exp Hematol, Vol.30 No.11, (November 2002), pp.1339-1345.

Bates, S.E.; Mickley, L.A.; Chen, Y.N.; Richert, N.; Rudick, J.; Biedler, J.L. \& Fojo, A.T. (1989). Expression of a drug resistance gene in human neuroblastoma cell lines: modulation by retinoic acid-induced differentiation. Mol Cell Biol, Vol.9, No.10, (October 1989), pp. 4337-4344.

Berman, D.M;, Karhadkar, S.S.; Hallahan, A.R.; Pritchard, J.I.; Eberhart, C.G.; Watkins, D.N.; Chen, J.K.; Cooper, M.K.; Taipale, J.; Olson, J.M. \& Beachy, P.A. (2002). Medulloblastoma growth inhibition by hedgehog pathway blockade. Science, Vol.297, no.5586, (August 2002), pp.1559-1561.

Blower, P.E.; Chung, J.H., Verducci, J.S.; Lin, S.; Park, J.K.; Dai, Z.; Liu, C.G.; Schmmittgen, T.D.; Reinhold, W.C.; Croce, C.M.; Weinstein, J.N. \& Sadee, W. (2008). MicroRNAs modulate the chemosensitivity of tumor cells. Mol Cancer Ther, Vol.7, No.1, (January 2008), pp.1-9.

Bonnet, D. \& Dick, J.E. (1997). Human acute myeloid leukemia is organized as a hierarchy that originates from a primitive hematopoietic cell. Nat Med, Vol.3, No.7, (July 1997), pp.730-737.

Boyer, L.A.; Lee, T.I.; Cole, M.F.; Johnstone, S.E.; Levine, S.S.; Zucker., J.P.; Guenther, M.G.; Kumar, R.M.; Murray, H.L.; Jenner, R.G.; Gifford, D.K.;. Melton, DA, Jaenisch, R, \& Young, RA. (2005). Core transcriptional regulatory circuitry in human embryonic stem cells. Cell, Vol.122, No.6, (September 2005), pp.947-956.

Budak, MT, Alpdogan, OS, Zhou, M, Lavker, RM, Akinci, MA, Wolosin, JM. (2005). Ocular surface epithelia contain ABCG2-dependent side population cells exhibiting features associated with stem cells. J Cell Sci, Vol.118, No.Pt 8, (April 2005), pp.1715-1724. 
Burger, H.; van Tol, H.; Boersma, A.W.; Brok, M.; Wiemer, E.A.; Stoter, G. \& Nooter, K. Imatinib mesylate (STI571) is a substrate for the breast cancer resistance protein (BCRP)/ ABCG2 drug pump. Blood, Vol.104, No.9, (November 2004), pp.2940-2942.

Calcagno, A.M.; Salcido, C.D.; Gillet, J.P.; Wu, C.P.; Fostel, J.M.; Mumau, M.D.; Gottesman, M.M.; Varticovski, L. \& Ambudkar, S.V. (2010). Prolonged drug selection of breast cancer cells and enrichment of cancer stem cell characteristics. J Natl Cancer Inst, Vol.102, No.21, (November 2010), pp.1637-1652.

Chen, Y.W.; Chen, K.H.; Huang, P.I.; Chen, Y.C.; Chiou, G.Y.; Lo, W.L.; Tseng, L.; Hsu, H.S.; Chang, K.W. \& Chiou, S.H. (2010). Cucurbitacin I suppressed stem-like property and enhanced radiation-induced apoptosis in head and neck squamous carcinomaderived CD44(+) ALDH(+) cells. Mol Cancer Ther, Vol.9, No.11, (Novermber 2010), pp.2879-2892.

Chiba, T.; Kita, K.; Zheng, Y.W.; Yokosuka, O.; Saisho, H.; Iwama, A.; Nakauchi, H. \& Taniguchi, H. (2006). Side population purified from hepatocellular carcinoma cells harbors cancer stem cell-like properties. Hepatology, Vol.44, No.1, (July 2006), pp.240-251.

Clarke, M.F.; Dick, J.F.; Dirks, P.B.; Eaves, C.J.; Jamieson, C.H.; Jones, D.L., Visvader, J.; Weissman, I.L. \& Wahl, G.M. (2006). Cancer stem cells - perspectives on current status and future directions: AACR Workshop on cancer stem cells. Cancer Res, Vol.66, No.19, (October 2006), pp.9339-9344.

Collins, A.T.; Berry, P.A.; Hyde, C.; Stower, M.J. \& Maitland, N.J. (2005). Prospective identification of tumorigenic prostate cancer stem cells. Cancer Res, Vol.65, No.23, (December 2005), pp.10946-10951.

Dittmar, T.; Nagler, C.; Schwitalla, S.; Reith, G.; Niggemann, B. \& Zanker, K.S. (2009) Recurrence cancer stem cells - Made by cell fusion? Med Hypotheses, Vol.73, No.4, (October 2009), pp.542-547.

Dou, J.; Pan, M.; Wen, P.; Li, Y.; Tang, Q.; Chu, L.; Zhao, F.; Jiang, C.; Hu, W.; Hu, K. \& Gu, N. (2007) Isolation and identification of cancer stem-like cells from murine melanoma cell lines. Cell Mol Immunol, Vol.4, No.6, (December 2007), pp.467-472.

Doyle, L.A.; Yang, W.; Abruzzo, L.V.; Krogmann, T.; Gao, Y.; Rishi, A.K. \& Ross, D.D. (1998). A multidrug resistance transporter from human MCF-7 breast cancer cells. Proc Natl Acad Sci USA, Vol.95, No.26, (December 1998), pp.15665-15670.

Du, Y.; Funderburgh, M.L.; Mann, M.M.; SundarRaji, N. \& Funderburgh, J.L. (2005). Multipotent stem cells in human corneal stroma. Stem Cells, Vol.23, No.9, (October 2005), pp.1266-1275.

Esquela-Kerscher, A. \& Slack, F.J. (2006). OncomiRs-microRNAs with a role in cancer. Nat Rev Cancer, Vol.6, No.4, (April 2006), pp.259-269.

Eyler, C.E. \& Rich, J.N. (2008). Survival of the fittest: cancer stem cells in therapeutic resistance and angiogenesis. J Clin Oncol, Vol.26, No.17, (June 2008), pp.2839-2845.

Fan, X.; Matsui, W.; Khaki, L.; Stearns, D.; Chun, J.; Li, Y.M.; Eberhart, C.G. (2006). Notch pathway inhibition depletes stem-like cells and blocks engraftment in embryonal brain tumors. Cancer Res, Vol.66, No.15, (August 2006), pp.7445-52.

Fang, D.D.; Kim, Y.J.; Lee, C.N.; Aggarwal, S.; McKinnon, K.; Mesmer, D.; Norton, J.; Birse, C.E.; He, T.; Ruben, S.M. \& Moore, P.A. (2010). Expansion of CD133(+) colon cancer cultures retaining stem cell properties to enable cancer stem cell target discovery. Br J Cancer, Vol.102, No.8, (April 2010), pp.1265-1275. 
Florek, M.; Haase, M.; Marzesco, A.M.; Freund, D.; Ehninger, G.; Huttner, W.B. \& Corbeil, D. (2005). Prominin-1/CD133, a neural and hematopoietic stem cell marker, is expressed in adult human differentiated cells and certain typrs of kidney cancer. Cell Tissue Res, Vol.319, No.1, (January 2005), pp.15-26.

Francipane, M.G.; Alea, M.P.; Lombardo, Y.; Todaro, M.; Medema, J.P. \& Stassi, G. (2008). Crucial role of interleukin- 4 in the survival of colon cancer stem cells. Cancer Res, Vol.68, No.11, (Jun 2008), pp.4022-4025.

Gallia, G.L.; Tyler, B.M.; Hann, C.L.; Siu, I.M.; Giranda, V.L.; Vescovi, A.L.; Brem, H. \& Riggins, G.J. (2009). Inhibition of Akt inhibits growth of glioblastoma and glioblastoma stem-like cells. Mol Cancer Ther, Vol.8, No.2, (February 2009), pp.386393.

Galimberti, S.; Guerrino, F.; Palumbo, G.A.; Consoli, U.; Fazzi, R.; Morabito, F.; Santini, V. \& Petrini, M. (2004). Evaluation of BCRP and MDR-1 co-expression by quantitative molecular assessment in AML patients. Leuk Res, Vol.28, No.4, (April 2004), pp.367372.

Gandhirajan, R.K.; Staib, P.A.; Minke, K.; Gehrke, I.; Plickert, G.; Schlosser, A.; Schmitt, E.K.; Hallek, M. \& Kreuzer, K.A. (2010). Small molecule inhibitors of Wnt/betacatenin/lef-1 signaling induces apoptosis in chronic lymphocytic leukaemia cells in vitro and in vivo. Neoplasia, Vol.12, No.4, (April 2010), pp.326-335.

Goodell, M.A.; Brose, K.; Paradis, G.; Conner, A.S. \& Mulligan R.C. (1996). Isolation and functional properties of murine hematopoietic stem cells that are replicating in vivo. J Exp Med, Vol.183, No.4, (April 1996), pp.1797-1806.

Goodell, M.A.; Rosenzweig, M.; Kim, H.; Marks, D.F.; DeMaria, M.; Paradis, G.; Grupp, S.A.; Sieff, C.A.; Mulligan, R.C. \& Johnson, R.P. (1997). Dye efflux studies suggest that hematopoietic stem cells expressing low or undetectable levels of CD34 antigen exist in multiple species. Nat Med, Vol.3, No.12, (December 1997), pp.1337-1345.

Gottesman, M.M. (2002). Mechanisms of cancer drug resistance. Annu Rev Med, Vol.53, pp.615-627.

Gottesman, M.M. \& Ambudkar, S.V. (2001). Overview: ABC transporters and human disease. J Bioenerg Biomembr, Vol.33, No.6, (December 2001), pp.453-458.

Gottesman, M.M.; Fojo, T.; Bates, S.E. (2002). Multidrug resistance in cancer: role of ATPdependent transporters. Nat Rev Cancer, Vol.2, No.1, (January 2002), pp.48-58.

Hambardzumyan, D.; Becher, O.J.; Rosenblum, M.K.; Pandolfi, P.P.; Manova-Todorova, K. \& Holland, EC. (2008). PI3K pathway regulates survival of cancer stem cells residing in the pervascular niche following radiation in medulloblastoma in vivo. Genes Dev, Vol.22, No.4, (February 2008), pp.436-448.

Hamburger, A.W. \& Salmon, S.E. (1977). Primary bioassay of human tumor stem cells. Science, Vol.197, No.4302, (July 1977), pp.461-463.

Hammond, S.M. (2007). MicroRNAs as tumor suppressors. Nat Genet, Vol.39, No.5, (May 2007), pp.582-583.

Haraquchi, N.; Ishii, H.; Mimori, K.; Tanaka, F.; Ohkuma, M.; Kim, H.M.; Akita, H.; Takiuchi, D.; Hatano, H.; Naqano, H.; Barnard, G.F.; Doki, Y. \& Mori, M. (2010). CD13 is a therapeutic target in human liver cancer stem cells. J Clin Invest, Vol.120, No.9, (September 2010), pp.3326-3339. 
He, J.; Sheng, T.; Stelter, A.A.; Li, C.; Zhang, X.; Sinha, M.; Luxon, B.A. \& Xie, J. (2006). Suppressing Wnt signalling by the hedgehog pathway through sFRP-1. J Biol Chem, Vol.281, No.47, (November 2006), pp.35598-35602.

Hegedus, T.; Orfi, L.; Seprodi, A.; Varadi, A.; Sarkadi, B.; Keri, G. (2002). Interaction of tyrosine kinase inhibitors with the human multidrug transporter proteins, MDR1 and MRP1. Biochim Biophys Acta, Vol.1587, No.2-3, (July 2002), pp.318-325.

Hemmati, H.D.; Nakano, I.; Lazareff, J.A.; Masterman-Smith, M.; Geschwind, D.H.; BronnerFraser, M. \& Kornblum, H.I. (2003). Cancerous stem cells can arise from pediatric brain tumors. Proc Natl Acad Sci USA, Vol.100, No.25, (December 2003), pp.1517815183.

Hirchmann-Jax, C.; Foster, A.E.; Wulf, G.G.; Nuchtern, J.G.; Jax, T.W.; Gobel, U.; Goodell, M.A. \& Brenner, M.K. (2004). A distinct "side population" of cells with high drug efflux capacity in human tumor cells. Proc Natl Acad Sci USA, Vol.101, No.39, (September 2004), pp.14228-14233.

Ho, M.M.; Hogge, D.E. \& Ling, V. (2008). MDR1 and BCRP1 expression in leukemic progenitors correlates with chemotherapy response in acute myeloid leukemia. Exp Hematol, Vol.36, No.4, (April 2008), pp.433-442.

Hong, S.P.; Wen, J.; Bang, S.; Park, S. \& Song, S.Y. (2009). CD44-positive cells are responsible for gemcitabine resistance in pancreatic cancer cells. Int J Cancer, Vol.125, No.10, (November 2009), pp.2323-2331.

Houghton, P.J.; Germain, G.S.; Harwood, F.C.; Schuetz, J.D.; Stewart, C.F.; Buchdunger, E. \& Traxler, P. (2004). Imatinib mesylate is a potent inhibitor of the ABCG2 (BCRP) transporter and reverses resistance to topotecan and SN-38 in vitro. Cancer Res, Vol.64, No.7, (April 2004), pp.2333-2337.

Hu, X.; Pandolfi, P.; Li, Y.; Koutcher, J.A.; Rosenblum, M. \& Holland, EC. (2005). mTOR promotes survival and astrocytic characteristics induced by Pten/AKT signalling in glioblastoma. Neoplasia, Vol.7, No.4, (April 2005), pp.356-368.

Hussain, S.Z.; Strom, S.C.; Kirby, M.R.; Burns, S.; Langemeiger, S.; Ueda, T.; Hsieh, M. \& Tisdale, J.F. (2005). Side population cells derived from adult human liver generate hepatocyte-like cells in vitro. Dig Dis Sci, Vol.50, No.10, (October 2005), pp.17551763.

Jamieson, C.H.; Ailles, L.E.; Dylla, SJ, Muijtjens, M.; Jones, C.; Zehnder, J.L.; Gotlib, J.; Li, K.; Manz, M.G.; Keating, A.; Sawyers, C.L. \& Weissman, I.L. (2004). Granulocytemacrophage progenitors as candidate leukemia stem cells in blast-crisis CML. $N$ Engl J Med, Vol.351, No.7, (August 2004), pp.657-667.

Jonker, J.W,; Buitelaar, M.; Wagenaar, E.; van der Valk, M.A.; Scheffer, G.L.; Scheper, R.J.; Plosch, T.; Kuipers, F.; Elferink, R.P.; Rosing, H.; Beijnen, J.H. \& Schinkel, A.H. (2002). The breast cancer resistance protein protects against a major chlorophyllderived dietary phototoxin and protoporphyria. Proc Natl Acad Sci USA, Vol.99, No.24, (November 2002), pp.15649-15654.

Juliano, R.L \& Ling, V. (1976). A surface glycoprotein modulating drug permeability in Chinese hamster ovary cell mutants. Biochim Biophys Acta, Vol.455, No.1, (November 1976), pp.152-162.

Kashyap, V.; Rezende, N.C.; Scotland, K.B.; Shaffer, S.M.; Persson, J.L.; Gudas, L.J. \& Mongan, NP. (2009). Regulation of stem cell pluriopotency and differentiation involves a mutual regulatory circuit of the NANOG, OCT4, and SOX2 
pluriopotency transcription factors with polycomb repressive complexes and stem cell microRNAs. Stem Cells Dev, Vol.18, No.7, (September 2009), pp.1093-1108.

Katoh, M. \& Katoh, M. (2007). Wnt signaling pathway and stem cell signaling network. Clin Cancer Res, Vol.13, No.14, (July 2007), pp.4042-4045.

Katoh, Y. \& Katoh, M. (2009). Hedgehog target genes: mechanisms of carcinogenesis induced by aberrant hedgehog signalling activation. Curr Mol Med, Vol.9, No.7, (September 2009), pp.873-886.

Kondo, T.; Setoguchi, T. \& Taga, T. (2004) Persistence of a small population of cancer stemlike cells in the C6 glioma cell line. Proc Natl Acad Sci USA, Vol.101, No.3, (January 2004), pp.781-786.

Kovalchuk, O.; Filkowski, J.; Meservy, J.; Ilnytskyy, Y.; Tryndyak, V.P.; Chekhun, V.F. \& Pogribny, I.P. (2008). Involvement of microRNA-451 in resistance of the MCF-7 breast cancer cells to chemotherapeutic drug doxorubicin. Mol Cancer Ther, Vol.7, No.7, (July 2008), pp.2152-2159.

Krivtsov, A.V.; Twomey, D. \& Feng, Z. et al. (2006). Transformation from committed progenitor to leukemia stem cell initiated by MLL-AF9. Nature, Vol.442, No.7104, (August 2006), pp.818-822.

Kuhnle, M.; Egger, M.; Muller, C.; Mahringer, A.; Bernhardt, G.; Fricker, G.; Konig, B. \& Buschauer, A. (2009). Potent and selective inhibitors of breast cancer resistance protein (ABCG2) derived from the p-glycoprotein (ABCB1) modulator tariquidar. $J$ Med Chem, Vol.52, No.4, (February 2009), pp.1190-1197.

Lapidot, T.; Sirard, C.; Vormoor, J.; Murdoch, B.; Hoang, T.; Caceres-Cortes, J.; Minden, M.; Paterson, B.; Caligiuri, M.A. \& Dick, J.E. (1994). A cell initiating human acute myeloid leukaemia after transplantation into SCID mice. Nature, Vol.367, No.6464, (Februaru 1994), pp.645-648.

Lechner, A.; Leech, C.A.; Abraham, E.J.; Nolan, A.L. \& Habener, J.F. (2002). Nestin-positive progenitor cells derived from adult human pancreatic islets of Langerhans contain side population (SP) cells defined by expression of the ABCG2 (BCRP1) ATPbinding cassette transporter. Biochem Biophys Res Comm, Vol..293, No.2, (May 2002), pp.670-674.

Lehar, S.M.; Dooley, J.; Farr, A.G. \& Bevan M.J. (2005). Notch ligands delta1 and jagged1 transmit distinct signals to T-cell precursors. Blood, Vol.105, No.4, (February 2005), pp.1440-1447.

Li, Z.; Hu, S.; Wang, J.; Cai, J.; Xiao, L.; Yu, L. \& Wang, Z. (2010). MiR-27a modulates MDR1/P-glycoprotein expression by targeting HIPK2 in human ovarian cancer cells. Gynecol Oncol, Vol.119, No.1, (October 2010), pp.125-130.

Liang, Z.; Wu, H.; Xia, J.; Li, Y.; Zhang, Y.; Huang, K.; Wagar, N.; Yoon, Y.; Cho, H.T.; Scala, S. \& Shim, H. (2010). Involvement of miR-326 in chemotherapy resistance of breast cancer through modulating expression of multidrug resistance-associated protein 1. Biochem Pharmacol, Vol.79, No.6, (March 2010), pp.817-824.

Liao, R.; Sun, J.; Zhang, L.; Lou, G.; Chen, M.; Zhou, D.; Chen, Z. \& Zhang, S. (2008). MicroRNAs play a role in the development of human hematopoietic stem cells. J Cell Biochem, Vol.104, No.3, (June 2008), pp.805-817.

Li, X.; Pan, Y.Z.; Seigel, G.M.; Hu, Z.H.; Huang, M. \& Yu, A.M. (2011). Breast cancer resistance protein BCRP/ABCG2 regulatory microRNAs (hsa-miR-328, -519c, - 
$520 \mathrm{~h})$ and their differential expression in stem-like ABCG2+ cancer cells. Biochem Pharmacol, Vol.81, No.6, (March 2011), pp.783-792.

Lu, J.; Getz, G.; Miska, E.A.; Alvarez-Saavedra, E.; Lamb, J.; Peck, D.; Sweet-Cordero, A.; Ebert, B.L.; Mak, R.H.; Ferradno, A.A.; Downing J.R.; Jacks, T.; Horvitz, H.R. \& Golub, T.R. (2005). MicroRNA expression profiles classify human cancers. Nature, Vol.435, No.7043, (June 2005), pp.834-838.

Marques, D.S.; Sandrini, J.Z.; Boyle, R.T.; Marins, L.F. \& Trindade, G.S. (2010). Relationships between multidrug resistance (MDR) and stem cell markers in human chronic myeloid leukemia cell lines. Leuk Res, Vol.34, No.6, (June 2010), pp.757-762.

Mickley, L.A.; Bates, S.E.; Richert, N.D.; Currier, S.; Tanaka, S.; Foss, F.; Rosen, N.; Fojo, A.T. (1989). Modulation of the expression of a multidrug resistance gene (mdr-1/Pglycoprotein) by differentiating agents. J Biol Chem, Vol.264, No.30, (October 1989), pp.18031-18040.

McGovern, M.; Voutev, R.; Maciejowski, J.; Corsi, A.K. \& Hubbard, E.J. (2009). A “latent niche" mechanism for tumor initiation. Proc Natl Acad Sci USA, Vol.106, No.28, (July 2009), pp.11617-11622.

Medina, V.; Calvo, M.B.; Diaz-Prado, S. \& Espada, J. (2009). Hedgehog signalling as a target in cancer stem cells. Clin Transl Oncol, Vol.11, No.4, (April 2009), pp.199-207.

Mishra, P.J.; Humeniuk, R. \& Mishra, P.J. (2007). A miR-24 microRNA binding site polymorphism in dihydrofolate reductase gene leads to methotrexate resistance. Proc Natl Acad Sci USA, Vol.104, No.33, (August 2007), pp.13513-13518.

Miyake, K.; Mickley, L.; Litman, T.; Zhan, Z.; Robey, R.; Cristensen, B.; Brangi, M.; Greenberger, K.; Dean, M.; Fojo, T. \& Bates, S.E. (1999). Molecular cloning of cDNAs which are highly overexpressed in mitoxantrone-resistant cells: demonstration of homology to ABC transport genes. Cancer Res, Vol.59, No.1, (January 1999), pp.8-13.

Mizoguchi, T.; Yamada, K.; Furukawa, T.; Hidaka, K.; Hisatsugu, T.; Shimazu, H.; Tsuruo, T.; Sumizawa, T. \& Akiyama, S. (1990) Expression of the MDR1 gene in human gastric and colorectal carcinomas. J Natl Cancer Inst, Vol.82, No.21, (November 1990), pp.1679-1683.

Montanaro, F.; Liadaki, K.; Schienda, J.; Flint, A.; Gussoni, E. \& Kunkel, L.M. (2004) Demystifying SP cell purification: Viability, yield, and phenotype are defined by isolation parameters. Exp Cell Res, Vol.298, No.1, (August 2004), pp.144-154.

Mueller, M.T.; Hermann, P.C.; Witthauer, J.; Rubio-Viqueira, B.; Leicht, S.F.; Huber, S.; Ellwart, J.W.; Mustafa, M.; Bartenstein, P.; D'Haese, J.G.; Schoenberg, M.H.; Berger, F.; Jauch, KW, Hidalgo, M, Heeschen, C. (2009). Combined targeted treatment to eliminate tumorigenic cancer stem cells in human pancreatic cancer. Gastroenterology, Vol.137, No.3, (September 2009), pp.1102-1113.

Naka, K.; Hoshii, T.; Muraguchi, T.; Tadokoro, Y.; Ooshio, T.; Kondo, Y.; Nakao, S.; Motoyama, N. \& Hirao, A. (2010). TGF-beta-FOXO signalling maintains leukaemiainitiating cells in chronic myeloid leukaemia. Nature, Vol.463, No.7281, (February 2010), pp.676-680.

Nishiyama, K.; Shirahama, T.; Yoshimura, A.; Sumizawa, T.; Furukawa, T.; IchikawaHaraguchi, M.; Akiyama, S. \& Ohi, Y. (1993). Expression of the multidrug transporter, P-glycoprotein, in renal and transitional cell carcinomas. Cancer, Vol.71, No.11, (June 1993), pp.3611-3619. 
Nowell, P.C. (1976). The clonal evolution of tumor cell populations. Science, Vol.194, No.4260, pp.23-28.

Pallini, R.; Ricci-Vitiani, L.; Montano, N.; Mollinari, C.; Biffoni, M.; Cenci, T.; Pierconti, F.; Martini, M.; De Maria, R. \& Larocca, L.M. (2011). Expression of the stem cell marker CD133 in recurrent glioblastoma and its value for prognosis. Cancer, Vol.117, No.1, (January 2011), pp.162-174.

Pan, Y.Z.; Morris, M.E. \& Yu, Z.M. (2009). MicroRNA-328 negatively regulates the expression of breast cancer resistance protein (BCRP/ABCG2) in human cancer cells. Mol Pharmacol, Vol.75, No.6, (June 2009), pp.1374-1379.

Park, C.H.; Bergsagel, D.E. \& McCulloch, E.A. (1971). Mouse myeloma tumor stem cells: a primary cell culture assay. J Natl Cancer Inst, Vol.46, No.2, (February 1971), pp.411422.

Pandey, P.R.; Okuda, H.; Watabe, M.; Pai, S.K.; Liu, W.; Kobayashi, A.; Xing, F.; Fukuda, K.; Hirota, S.; Sugai, T.; Wakabayashi, G.; Koeda, K.; Kashiwaba, M.; Suzuki, K.; Chiba, T.; Endo, M.; Fujioka, T.; Tanji, S.; Mo, Y.Y.; Cao, D.; Wilber, A.C. \& Watabe, K. (2010). Resveratrol suppresses growth of cancer stem-like cells by inhibiting fatty acid synthase. Breast Cancer Res Treat, (December 2010), DOI 10.1007/s10549-0101300-6

Pasca di Magliano, M. \& Hebrok, M. (2003). Hedgehog signalling in cancer formation and maintenance. Nat Rev Cancer, Vol.3, No.12, (December 2003), pp.903-911.

Pawelek, J.M. \& Chakraborty, A.K. (2008). Fusion of tumor cells with bone marrow-derived cells: a unifying explanation for metastasis. Nat Rev Cancer, Vol.8, No.5, (May 2008), pp.377-386.

Patrawala, L.; Calhoun, T.; Schneider-Broussard, R.; Zhou, J.; Claypool, K. \& Tang, D.G. (2005). Side population is enriched in tumorigenic, stem-like cancer cells, whereas ABCG2+ and ABCG2- cancer cells are similarly tumorigenic. Cancer Res, Vol.65, No.14, (July 2005), pp.6207-6219.

Phillips, T.M.; McBride, W.H. \& Pajonk, F. (2006). The response of CD24-/low/CD44+ breast cancer-initiaiting cells to radiation. I Natl Cancer Inst, Vol.98, No.24, (December 2006), pp.1777-1785.

Plasilova, M.; Zivny, J.; Jelinel, J.; Neuwirtova, R.; Cermak, J.; Encas, E.; Andera, L. \& Stopka, T. (2002) TRAIL (Apo2L) suppresses growth of primary human leukaemia and myelodysplasia progenitors. Leukemia, Vol.16, No.1, (January 2002), pp.67-73.

Polgar, O.; Robey, R.W. \& Bates, S.E. (2008). ABCG2: structure, function and role in drug response. Expert Opin Drug Metab Toxicol, Vol.4, No.1, (January 2008), pp.1-15.

Reya, T. \& Clevers, H. (2005). Wnt signalling in stem cells and cancer. Nature, Vol.434, No.7035, (April 2005), pp.843-850.

Ross, D.D. \& Hakanishi, T. (2010). Impact of breast cancer resistance protein on cancer treatment outcomes, In: Multidrug resistance in cancer, Humana Press.

Salnikov, A.V.; Gladkich, J.; Moldenhauer, G.; Volm, M.; Mattern, J. \& Herr, I. (2010). CD133 is indicative for a resistance phenotype but does not represent a prognostic marker for survival of non-small cell lung cancer patients. Int J Cancer, Vol.126, No.4, (February 2010), pp.950-958.

Sandor, V.; Fojo, T. \& Bates, S.E. (1998). Future perspectives for the development of Pglycoprotein modulators. Drug Resist Updat, Vol.1, No.3, pp.190-200. 
Sarker, D.; Reid, A.H.; Yap, T.A. \& de Bono, J.S. (2009). Targeting the PI3K/AKT pathway for the treatment of prostate cancer. Clin Cancer Res, Vol.15, No.15, (August 2009), pp.4799-4805.

Scharenberg, C.W.; Harkey, M.A.\& Torok-Storb, B. (2002). The ABCG2 transporter is an efficient Hoechst 33342 efflux pump and is preferentially expressed by immature human hematopoietic progenitors. Blood, Vol.99, No.2, (January 2002), pp.507-512.

Scharpfenecker, M.; Kruse J.J.; Sprong, D.; Russell, N.S.; ten Dijke, P.; Stewart, F.A. (2009). Ionizing radiation shifts the PAI-1/ID-1 balance and activates notch signaling in endothelial cells. Int J Rad Oncol Biol Phys, Vol.73, No.2, (February 2009), pp.506513.

Schinkel, A.H.; Smit, J.J.; van Tellingen, O.; Beijnen, J.H.; Wagenaar, E.; van Deemter, L.; Mol, C.A.; van der Valk, M.A.; Robanus-Maandag, E.C. \& te Riele, H.P. (1994). Disruption of the mouse mdr1a P-glycoprotein gene leads to a deficiency in the blood-brain barrier and to increased sensitivity to drugs. Cell, Vol.77, No.4, (May 1994), pp.491-502.

Schmidt, P.; Kopecky, C.; Hombach, A.; Zigrino, P.; Mauch, C. \& Abken, H. (2011). Eradication of melanomas by targeted elimination of a minor subset of tumor cells. Proc Natl Acad Sci USA, Vol.108, No.6, (February 2011), pp.2474-2479.

Seigel, G.M.; Campbell, L.M.; Narayan, M. \& Gonzalez-Fernandez, F. (2005). Cancer stem cell characteristics in retinoblastoma. Mol Vis, Vol.11, (September 2005), pp.729-737.

Shafa, M.; Krawetz, R. \& Rancourt, D.E. (2010). Returning to the stem state: epigenetics of recapitulating pre-differentiation chromatin structure. Bioessays, Vol.32, No.9, (September 2010), pp.791-799.

Shmelkov, S.V.; St Clair, R.; Lyden, D.; Rafii, S. (2005). AC133/CD133/prominin-1. Int J Biochem Cel Biol, Vol.37, No.4, (April 2005), pp.715-719.

Singh, S.K.; Clarke, I.D.; Terasaki, M.; Bonn, V.E.; Hawkins, C.; Squire, J. \& Dirks, P.B. (2003) Identification of a cancer stem cell in human brain tumors. Cancer Res, Vol.63, No.18, (September 2003), pp.5821-5828.

Singh, S.K.; Hawkins, C.; Clarke, I.D.; Squire, J.A.; Bayani, J.; Hide, T.; Henkelman, R.M.; Cusimano, M.D. \& Dirks, P.B. (2004) Identification of human brain tumor initiating cells. Nature, Vol.432, No.7015, (November 2004), pp.396-401.

Stadler, B.M. \& Ruohola-Baker, H. (2008). Small RNAs: keeping stem cells in line. Cell, Vol.132, No.4, (February 2008), pp.563-566.

Steinbach, D.; Sell, W.; Voigt, A.; Hermann, J.; Zintl, F. \& Sauerbrey, A. (2002). BCRP gene expression is associated with a poor response to remission induction therapy in childhood acute myeloid leukemia. Leukemia, Vol.16, No.8, (August 2002), pp.14431447.

Summer, R.; Kotton, D.N.; Sun, X.; Ma, B.; Fitzsimmons, K. \& Fine, A. (2003). Side population cells and Bcrp1 expression in lung. Am J Physiol Lung Cell Mol Physiol, Vol.285, No.1, (July 2003), pp.L97-L104.

Tagscherer, K.E.; Fassl, A.; Campos, B.; Farhadi, M.; Kraemer, A.; Bock, B.C.; MacherGoeppinger, S.; Radlwimmer, B.; Wiestler, O.D.; Herold-Mende, C. \& Roth, W. (2008). Apoptosis-based treatment of glioblastomas with ABT-737, a novel small molecule inhibitor of Bcl-2 family proteins. Oncogene, Vol.27, No.52, (November 2008), pp.6646-6656. 
Tamaki, S.; Eckert, K.; He, D.; Sutton, R.; Doshe, M.; Jain, G.; Tushinski, R.; Reitsma, M.; Harris, B.; Tsukamoto, A.; Gage, F.; Weissman, I. \& Uchida, N. (2002). Engraftment of sorted/expanded human central nervous system stem cells from fetal brain. $J$ Neurosci Res, Vol.69, No.6, (September 2002), pp.976-986.

To, K.K.; Polgar, O.; Huff, L.M.; Morisaki, K.; Bates, S.E. (2008a). Histone modifications at the ABCG2 promoter following treatment with histone deacetylase inhibitor mirror those in multidrug-resistant cells. Mol Cancer Res, Vol.6, No.1, (January 2008), pp.151-164.

To, K.K.; Zhan, Z.; Litman, T. \& Bates, S.E. (2008b). Regulation of ABCG2 expression at the 3 'untranslated region of its mRNA through modulation of transcript stability and protein translation by a putative microRNA in the S1 colon cancer cell line. Mol Cell Biol, Vol.28, No.17, (September 2008), pp.5147-5161.

To, K.K.; Robey, R.W.; Knutsen, T.; Zhan, Z.; Ried, T.; Bates, S.E. (2009). Escape from hsamiR-519c enables drug-resistant cells to maintain high expression of ABCG2. Mol Cancer Ther, Vol.8, No.10, (October 2009), pp.2959-2968.

To, K.K.; Robey, R.W.; Zhan, Z.; Bangiolo, L.; Bates, S.E. (2011). Upregulation of ABCG2 by romidepsin via the aryl hydrocarbon receptor pathway. Mol Cancer Res, (Feb 2011) [Epub ahead of print].

Triel, C.; Vestergaard, M.E.; Bolund, L.; Jensen, T.G. \& Jensen, U.B. (2004). Side population cells in human can mouse epidermis lack stem cell characteristic. Exp Cell Res, Vol.295, No.1., (April 2004), pp.79-90.

Van den Heuvel-Eibrink, M.M.; van der Holt, B.; Burnett, A.K.; Knauf, W.U.; Fey, M.F.; Verhoef, G.E.; Vellenga, E.; Ossenkoppele, G.J.; Lowenberg, B. \& Sonneveld, P. (2007). CD34-related coexpression of MDR1 and BCRP indicates a clinically resistant phenotype in patients with acute myeloid leukemia (AML) of older age. Ann Hematol, Vol.86, No.5., pp.329-337.

Vasiliou, V.; Vasiliou, K. \& Kebert, D.W. (2009). Human ATP-binding cassette (ABC) transporter family. Hum Genomics, Vol.3, No.3, (April 2009), pp.281-290.

Virchow, R. (1855). Editorial. Virchows Arch Pathol Anat Physiol Klin Med, Vol.3, pp.23.

Wang, F.; Xue, X.; Wei, J.; An, Y.; Yao, J.; Cai, H.; Wu, J.; Dai, C.; Qian, Z.; Xu, Z. \& Maio, Y. (2010). hsa-miR-520h downregulates ABCG2 in pancreatic cancer cells to inhibit migration, invasion, and side populations. Br J Cancer, Vol.103, No.4, (August 2010), pp.567-574.

Wang, K.H.; Kao, A.P.; Chang, C.C.; Lee, J.N.; Hou, M.F.; Long, C.Y.; Chen, H.S. \& Tsai E.M. (2010). Increasing CD44+/CD24(-) tumor stem cells, and upregulation of COX-2 and HDAC6, as major functions of HER2 in breast tumorigenesis. Mol Cancer, Vol.9, (November 2010), pp.288.

Wang, X.K. \& Fu, L.W. (2010). Interaction of tyrosine kinase inhibitors with the MDR-related ABC transporter proteins. Curr Drug Metab, Vol.11, No.7, (September 2010), pp.618628.

Welte, Y.; Adjaye, J.; Lehrach, H.R. \& Regenbrecht, C.R. (2010) Cancer stem cells in solid tumors: elusive or illusive? Cell Commun Signal, Vol.8, No.1, (May 2010), pp.6.

Wend, P.; Holland, J.D.; Ziebold, U. \& Birchmeier, W. (2010). Wnt signaling in stem and cancer stem cells. Semin Cell Dev Biol, Vol.21, No.8, (October 2010), pp.855-863.

Woodward, W.A.; Chen, M.S.; Behbod, F. \& Rosen, J.M. (2005). On mammary stem cells. J Cell Sci, Vol.118, No.Pt16, (August 2005), pp.3585-3594. 
World Health Organization (2008) World Cancer Report 2008. ISBN 978-92-832-0423-7, WHO, Geneva.

Xia, L.; Zhang, D.; Du, R.; Pan, Y.; Zhao, L.; Sun, S.; Hong, L.; Liu, J. \& Dan, D. (2008). miR$15 \mathrm{~b}$ and miR-16 modulate multidrug resistance by targeting BCL2 in human gastric cancer cells. Int J Cancer, Vol.123, No.2, (July 2008), pp.372-379.

Yilmaz, O.H.; Valdez, R.; Theisen, B.K.; Guo, W.; Ferguson, D.O.; Wu, H. \& Morrison, S.J. (2006). Pten dependence distinguishes haematopoietic stem cells from leukemiainitiating cells. Nature, Vol.441, No.7092, (May 2006), pp.475-482.

Zhao, C.; Blum, J.; Chen, A.; Kwon, H.Y.; Jung, S.H.; Cook, J.M.; Lagoo, A. \& Rey, T. (2007) Loss of $\beta$-catenin impairs the renewal of normal and CML stem cells in vivo. Cancer Cell, Vol.12, No.6, (December 2007), pp.528-541.

Zhou, S.; Schuetz, J.D.; Bunting, K.D.; Colapietro, A.M.; Sampath, J.; Morris, J.J.; Lagutina, I.; Grosveld, G.C.; Osawa, M.; Nakauchi, H. \& Sorrentino, B.P. (2001). The ABC transporter Bcrp1/ABCG2 is expressed in a wide variety of stem cells and is a molecular determinant of the side-population phenotype. Nat Med, Vol.7, No.9, (September 2001), pp.1028-1034.

Zhou, S.; Morris, J.J.; Barnes, Y.; Lan, L.; Schuetz, J.D.; Sorrentino, B.P. (2002). Bcrp1 gene expression is required for normal numbers of side population stem cells in mice, and confers relative protection to mitoxantrone in hematopoietic cells in vivo. Proc Natl Acad Sci USA, Vol.99, No.19, (September 2002), pp.12339-11344.

Zhu, H.; Wu, H.; Liu, X.; Evans, B.R.; Medina, D.J.; Liu, C.G. \& Yang, J.M. (2008). Role of microRNA miR-27a and miR-451 in the regulation of MDR1/P-glycoprotein expression in human cancer cells. Biochem Pharmacol, Vol.76, No.5, (September 2008), pp.582-588. 


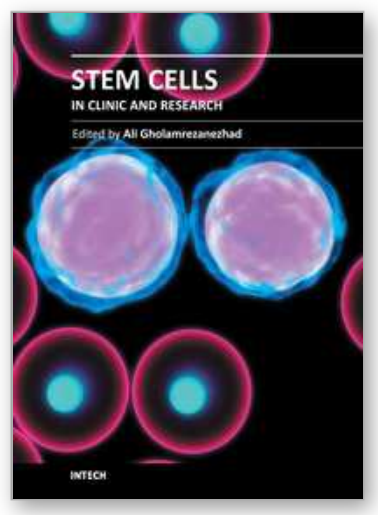

\author{
Stem Cells in Clinic and Research \\ Edited by Dr. Ali Gholamrezanezhad
}

ISBN 978-953-307-797-0

Hard cover, 804 pages

Publisher InTech

Published online 23, August, 2011

Published in print edition August, 2011

Based on our current understanding of cell biology and strong supporting evidence from previous experiences, different types of human stem cell populations are capable of undergoing differentiation or trans-differentiation into functionally and biologically active cells for use in therapeutic purposes. So far, progress regarding the use of both in vitro and in vivo regenerative medicine models already offers hope for the application of different types of stem cells as a powerful new therapeutic option to treat different diseases that were previously considered to be untreatable. Remarkable achievements in cell biology resulting in the isolation and characterization of various stem cells and progenitor cells has increased the expectation for the development of a new approach to the treatment of genetic and developmental human diseases. Due to the fact that currently stem cells and umbilical cord banks are so strictly defined and available, it seems that this mission is investigationally more practical than in the past. On the other hand, studies performed on stem cells, targeting their conversion into functionally mature tissue, are not necessarily seeking to result in the clinical application of the differentiated cells; In fact, still one of the important goals of these studies is to get acquainted with the natural process of development of mature cells from their immature progenitors during the embryonic period onwards, which can produce valuable results as knowledge of the developmental processes during embryogenesis. For example, the cellular and molecular mechanisms leading to mature and adult cells developmental abnormalities are relatively unknown. This lack of understanding stems from the lack of a good model system to study cell development and differentiation. Hence, the knowledge reached through these studies can prove to be a breakthrough in preventing developmental disorders. Meanwhile, many researchers conduct these studies to understand the molecular and cellular basis of cancer development. The fact that cancer is one of the leading causes of death throughout the world, highlights the importance of these researches in the fields of biology and medicine.

\title{
How to reference
}

In order to correctly reference this scholarly work, feel free to copy and paste the following:

To, Kenneth K.W. and Fu, L.W. (2011). Multidrug Resistance Transporters - Roles in maintaining Cancer Stem-Like Cells, Stem Cells in Clinic and Research, Dr. Ali Gholamrezanezhad (Ed.), ISBN: 978-953-307-7970, InTech, Available from: http://www.intechopen.com/books/stem-cells-in-clinic-and-research/multidrugresistance-transporters-roles-in-maintaining-cancer-stem-like-cells

\section{INTECH}

open science | open minds 


\section{InTech Europe}

University Campus STeP Ri

Slavka Krautzeka 83/A

51000 Rijeka, Croatia

Phone: +385 (51) 770447

Fax: +385 (51) 686166

www.intechopen.com

\section{InTech China}

Unit 405, Office Block, Hotel Equatorial Shanghai

No.65, Yan An Road (West), Shanghai, 200040, China

中国上海市延安西路65号上海国际贵都大饭店办公楼 405 单元

Phone: +86-21-62489820

Fax: $+86-21-62489821$ 
(C) 2011 The Author(s). Licensee IntechOpen. This chapter is distributed under the terms of the Creative Commons Attribution-NonCommercialShareAlike-3.0 License, which permits use, distribution and reproduction for non-commercial purposes, provided the original is properly cited and derivative works building on this content are distributed under the same license. 